\title{
On inclusion of water resource management in Earth system models - Part 1: Problem definition and representation of water demand
}

\author{
A. Nazemi and H. S. Wheater \\ Global Institute for Water Security, University of Saskatchewan, 11 Innovation Boulevard, Saskatoon, SK, S7N 3H5, Canada \\ Correspondence to: A. Nazemi (ali.nazemi@usask.ca)
}

Received: 12 June 2014 - Published in Hydrol. Earth Syst. Sci. Discuss.: 21 July 2014

Revised: 8 November 2014 - Accepted: 25 November 2014 - Published: 7 January 2015

\begin{abstract}
Human activities have caused various changes to the Earth system, and hence the interconnections between human activities and the Earth system should be recognized and reflected in models that simulate Earth system processes. One key anthropogenic activity is water resource management, which determines the dynamics of human-water interactions in time and space and controls human livelihoods and economy, including energy and food production. There are immediate needs to include water resource management in Earth system models. First, the extent of human water requirements is increasing rapidly at the global scale and it is crucial to analyze the possible imbalance between water demands and supply under various scenarios of climate change and across various temporal and spatial scales. Second, recent observations show that human-water interactions, manifested through water resource management, can substantially alter the terrestrial water cycle, affect land-atmospheric feedbacks and may further interact with climate and contribute to sea-level change. Due to the importance of water resource management in determining the future of the global water and climate cycles, the World Climate Research Program's Global Energy and Water Exchanges project (WRCPGEWEX) has recently identified gaps in describing humanwater interactions as one of the grand challenges in Earth system modeling (GEWEX, 2012). Here, we divide water resource management into two interdependent elements, related firstly to water demand and secondly to water supply and allocation. In this paper, we survey the current literature on how various components of water demand have been included in large-scale models, in particular land surface and global hydrological models. Issues of water supply and allocation are addressed in a companion paper. The available algorithms to represent the dominant demands are
\end{abstract}

classified based on the demand type, mode of simulation and underlying modeling assumptions. We discuss the pros and cons of available algorithms, address various sources of uncertainty and highlight limitations in current applications. We conclude that current capability of large-scale models to represent human water demands is rather limited, particularly with respect to future projections and coupled landatmospheric simulations. To fill these gaps, the available models, algorithms and data for representing various water demands should be systematically tested, intercompared and improved. In particular, human water demands should be considered in conjunction with water supply and allocation, particularly in the face of water scarcity and unknown future climate.

\section{Background and scope}

\subsection{Large-scale modeling - an introduction to land-surface and global hydrological models}

The Earth system is an integrated system that unifies the physical processes at the Earth's surface. These processes include a wide range of feedbacks and interactions between and within the atmosphere, land and oceans and cover the global cycles of climate, water and carbon that support planetary life (e.g., Schellnhuber, 1999; Kump et al., 2010). From the advent of digital computers, Earth system models have been a key tool to identify past changes and to predict the future of planet Earth. These models normally include submodels that represent various functions of the land, atmosphere and oceans (Claussen, 2001; Schlosser et al., 2007). A crucial sub-model in Earth system models is the landsurface model (LSM) that represents the land portion of the 
Earth system. LSMs contain interconnected computational modules that characterize physical processes related to soil, vegetation and water over a gridded mesh, and account for their influences on water, energy and, increasingly, carbon exchanges. A wide range of LSMs is currently available, and these can be differentiated based on how, and to what extent, different land-surface processes are represented; nonetheless, a LSM should explicitly or implicitly include the dynamics of these processes, and account for their drivers at various temporal and spatial scales (see Trenberth, 1992; Sellers, 1992).

The importance of representing the terrestrial water cycle in LSMs is well-established (see Pitman, 2003, and references therein), and there has been progressive development of LSMs in representing various components of the hydrologic cycle, such as soil moisture, vegetation, snowmelt and evaporation. In early LSMs, hydrology was conceptualized as a simple lumped bucket model (Manabe, 1969), but this representation has progressively been improved by including more complexity and explicit physics in canopy, soil moisture and runoff calculations (see Deardorff, 1978; Dickinson, 1983, 1984; Sellers et al., 1986, 1994, 1996a; Nicholson, 1988; Pitman et al., 1990). Despite these improvements, major limitations and uncertainties remain in the hydrological simulations, causing systematic bias in water and energy balance calculations. These deficiencies have been attributed (in part) to unrealistic assumptions and incomplete parameterizations of catchment response in LSMs (Soulis et al., 2000; Music and Caya, 2007; Sulis et al., 2011). Further attempts, therefore, have focused on including catchment-scale runoff generation and routing processes (e.g., Miller et al., 1994; Hagemann and Dümenil, 1997; Oki and Sud, 1998; Oleson et al., 2008; Lawrence et al., 2011). These components determine the hydrological response at the larger scales and have been frequently used in large-scale hydrological models, socalled global hydrologic models (GHMs). Similar to LSMs, GHMs are gridded large-scale models; however, they are typically simpler in structure and focus on representing the water cycle rather than other land-surface processes (such as the energy and carbon cycles). LSMs have been applied frequently in regional and global modeling (e.g., Liang et al., 1994; Pietroniro et al., 2007; Adam et al., 2007; Livneh et al., 2011) and compared to GHMs (see Haddeland et al., 2011). At this stage of research, however, both LSMs and GHMs are still imperfect and incomplete, as current simulations cannot match recent hydrological observations (see Lawrence et al., 2012).

\subsection{Modeling human-water interactions}

While external forcing, mainly the energy flux from the Sun, is the main driver of the Earth system, internal disturbances such as volcanic eruptions, wildfires and human activities can substantially affect the natural Earth system cycles (Vitousek et al., 1997; Trenberth and Dai, 2007; Bowman et al.,
2009). In particular, post-industrial human activities, from the mid-20th century onwards, have severely perturbed the Earth system (Crutzen and Steffen, 2003; Crutzen, 2006). This has initiated a new geological epoch, informally termed the "Anthropocene", in which it is recognized that the natural processes within the land surface system are highly controlled and regulated by humans (see McNeil, 2000; Steffen et al., 2007, 2011). Accordingly, Earth system models should address feedbacks and interactions between the natural Earth system and the anthroposphere, which includes human cultural and socio-economic activities (Schellnhuber, 1998, 1999; Claussen, 2001). The terrestrial water cycle is one set of Earth system processes that is greatly perturbed by human activities; it also is of critical importance in determining human health, safety and livelihoods, as well as local, regional and global economies (e.g., Nilsson et al., 2005). However, although some anthropogenic effects, such as the emission of greenhouse gases and land-use change, have been incorporated in LSMs (e.g., Lenton, 2000; Zhao et al., 2001; Karl and Trenberth, 2003; Brovkin et al., 2006; Solomon et al., 2009), less effort has been made to represent human-water interactions (e.g., Trenberth and Asrar, 2012; Lawrence et al., 2012; Oki et al., 2013). This can be a major reason for current deficiencies in hydrological performance of large-scale modes (i.e., LSMs and/or GHMs). In fact, large-scale models still widely assume that human effects on the terrestrial water cycle can be ignored. This assumption is highly questionable and can result in the neglect of important hydrologic processes (see Gleick et al., 2013).

Human-water interactions include a wide spectrum of anthropogenic interventions, including land-use change and water resource management. During the past century, human water consumption has increased more than 6-fold, with around 5, 18 and 10 times increase in agricultural, industrial and municipal consumption, respectively (see Shiklomanov, 1993, 1997, 2000). Supplying such intensive demands has required large changes in the natural water cycle - which can be even more than the effects of warming climate (see Haddeland et al., 2014), and is associated with major environmental water stress at the global scale. Smakhtin et al. (2004) concluded that over 1.4 billion people currently live in river basins with high environmental water stress and this number will increase as water withdrawals grow. For instance, surface-water withdrawals for supplying human needs decrease downstream flows, often substantially, and result in seasonal decline in flows of major rivers such as the Colorado River (e.g., Cayan et al., 2010). Similarly, dam operations considerably change the timing, volume, peak and the age of natural streamflow and reduce inputs to wetlands, lakes and seas (e.g., Vörösmarty et al., 1997, 2005; Vörösmarty and Sahagian, 2000; Meybeck, 2003; Tang et al., 2010). This is associated with some extreme effects, such as the death of the Aral Sea (e.g., Precoda, 1991; Small et al., 2001) and aggressive decline in the area of Lake Urmia in Iran (Aghakouchak et al., 2014). In parallel, groundwater abstractions are asso- 
ciated with declining groundwater levels, reduced baseflow contributions and loss of wetlands. For instance, current assessments reveal significant groundwater depletion in some areas of the globe, such as Indian peninsula, the US Midwest, and Iran (Giordano, 2009; Rodell et al., 2009; Gleeson et al., 2012; Döll et al., 2014). Without considering human withdrawals, these changes in surface-water and groundwater availability cannot be captured by large-scale models. It should be noted that human activities have large effects on water quality as well. For instance, extensive groundwater pumping is also associated with potential long-term contamination, for example by salt-water intrusion (Sophocleous, 2002; Antonellini et al., 2008), and nutrient pollution of surface and groundwater is an outstanding global challenge. These water quality impacts, however, remain beyond the scope of this survey.

As human life and water availability are tightly interconnected (see Sivapalan et al., 2012), current and future changes in the water availability are not only important for Earth system modeling, but are also of major importance to human society, and these issues can be explored to a large extent with large-scale models. Although human water use still accounts for a small proportion of total water on and below the surface (see Oki and Kanae, 2006), total human withdrawals currently include around $26 \%$ of terrestrial evaporation and $54 \%$ of the accessible surface runoff that is geographically and temporally available (Postel et al., 1996). There are already major water scarcity issues across highly populated regions of the globe (e.g., Falkenmark, 2013; Schiermeier, 2014), which raise fundamental concerns about how future demand should be supplied, particularly considering climate change (e.g., Arnell, 1999, 2004; Tao et al., 2003; Döll, 2009; Taylor et al., 2013; Hanasaki et al., 2013a, b; Wada et al., 2013; Milano et al., 2013; Mehta et al., 2013; Schewe et al., 2014). Such important threats to water security necessitate a detailed understanding of water availability and demand in time and space; and therefore largescale models are required for impact assessments.

Apart from the hydrologic and water security relevance discussed above, human-water interactions can have broader implications for the water cycle and affect climate, although these issues are yet to be fully explored, and remain in some cases controversial. For instance, irrigation can disturb the "natural" atmospheric boundary conditions (e.g., Sacks et al., 2009; Destouni et al., 2010; Gerten et al., 2011; Pokhrel et al., 2012; Hossain et al., 2012; Guimberteau et al., 2012; Dadson et al., 2013). At this stage of model development, the available quantitative understanding of these landatmospheric implications is limited. To explore these issues it is necessary to include these processes in coupled landatmospheric models, and this requires explicit representation of relevant human-water interactions within LSM computational schemes. Moreover, the return flows from human usage, entering the seas and oceans, can affect salinity and temperature and consequently impact their circulation patterns (e.g., Rohling and Bryden, 1992; Skliris and Lascaratos, 2004; Vargas-Yàñez et al., 2010). This is of particular concern for closed oceans and the polar environment, where a change in freshwater input can modify the oceanic circulations and thus feedback on continental rainfall (Polcher, 2014). However as noted above, issues related to water quality remain beyond the scope of our survey.

\subsection{Aim and scope of this survey}

The aim of our survey is to consider the associated scientific and data challenges, the state of current practice, and directions for future research around including human effects on the terrestrial water cycle. In this paper and a companion paper (hereafter Nazemi and Wheater, 2015), we focus on human-water activities manifested through water resource management and note that this is subject to operational and policy constraints. We only consider water quantity aspects of water resource management, which we define as a suite of anthropogenic activities related to storage, abstraction and redistribution of available water sources for various human demands. Although a fully coupled representation of water resource management in Earth system models is not currently available, important progress is being made, and more generally a body of literature is gradually shaping around describing different aspects of water resource management in large-scale models, in particular within the context of GHMs. Nonetheless, there are still fundamental obstacles in including water resource management within large-scale models.

First, a fundamental principle in Earth system models as well as LSMs and GHMs is the conservation of water. To represent water resource management, therefore, it is necessary to fully capture water in a coupled human-natural system. To achieve this (i) modeling complexity should be increased, (ii) process representations related to both natural and anthropogenic systems should be improved and (iii) modeling capability should be extended to new domains (see Polcher, 2014, for an in-depth discussion). For instance, a large proportion of human demand is supplied by groundwater, which is often absent or crudely represented in both LSMs and GHMs and is widely considered disjoint from other elements of the Earth system such as climate.

Second, multiple factors affect water resource management at the larger scales, such as climate, hydrology, landcover and socio-economy as well as land and environment management. Moreover, real-world management decisions often include cultural values and political concerns (Gober and Wheater, 2014). These various influences are so far considered in isolation and the interactions among them are widely unseen (e.g., Beddington, 2013).

Third, there is considerable lack of regional and global data concerning the actual use and operation of water resources systems, and therefore large-scale models cannot be properly tuned or validated. This major limitation, for instance, has led the research community to use estimated de- 
mand as a surrogate for actual use. Lack of data about human operations can also introduce large uncertainty into simulations of terrestrial storage and runoff. For instance Gao et al. (2012) noted that the "[...] results from global reservoir simulations are questionable" as "there are no direct observations of reservoir storage".

Fourth, there is a major gap between the scope of local operational water resource models and large-scale applications and research needs. Essentially, the scale at which local water resource management takes place is often within the sub-grid resolution of current large-scale models, which requires narrowing the resolution in large-scale models for explicit representation (see Wood et al., 2011) or adding more sub-grid heterogeneity into grid calculations for implicit parameterization. In addition, there is (and will increasingly be) competition between various water demands which requires allocation decisions. At this stage of model development, however, it is still unclear how operational policies should best be reflected at larger scales. At the local scale, detailed information on physical and operational systems as well as climate and water supply conditions are available (or can be generated as scenarios; see, e.g., Nazemi et al., 2002, 2013; Nazemi and Wheater, 2014a, b) and the competition between demands is often reflected as an optimization problem. As the simulation scale moves from local and small basin scales to regional and global scales, the data availability degrades considerably and the high level of calculations within optimization algorithms cannot be maintained, due to computational barrier.

Conceptually, water resource management at larger scales can be seen as an integration of two fully interactive elements, related to water demand as well as water supply and allocation: water demand is constrained by water availability and drives water allocation, which results in extraction from water sources and determines the extent of change in hydrological elements of the land surface. Moreover, as noted briefly above, perturbations in the terrestrial water cycle due to water resource management can further interact with other elements of the Earth system, particularly with climate (see Fig. 1). To assess the impacts of water resource management on land-surface processes and associated feedbacks with climate, the elements of water demand and water allocation should be described using computational algorithms and included in large-scale models. For the purpose of our survey, and reflecting the state of algorithm development and data availability, we focus in this paper only on the representation of water demand, and in the Nazemi and Wheater (2015) on water supply and allocation. Here, we classify human water demands under two general categories, namely irrigative and non-irrigative, and further divide nonirrigative demands into municipal, industrial, environmental, energy-related, and livestock water needs. This is useful to put current algorithms and modeling applications into context. Accordingly, we discuss how these demands are characterized using various computational algorithms. As will be

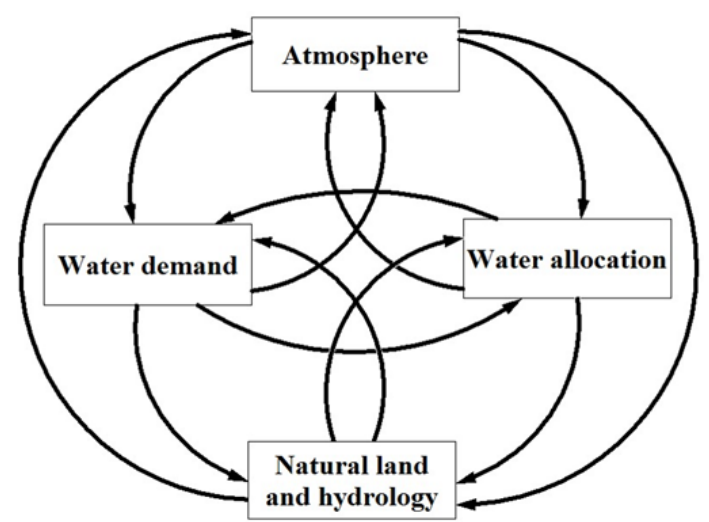

Figure 1. Water resource management as an integration of water demand and water allocation and its interactions with natural landsurface and climate.

shown later in this paper, human demands are mainly quantified either using downscaling (i.e., top-down approaches) or through direct modeling at the grid scale (i.e., bottomup approaches). Depending on the type of application, the algorithms can be included in a wide range of large-scale models. Throughout our review, we consider both offline and online implications of water demand. Offline simulations assess the effects of water demand on land-surface processes without considering the associated feedbacks to the climate system, but can be linked to atmospheric driving variables to simulate land-surface and/or hydrological responses to climate and water resource management. Online models also account for the effects of water demand on land-atmospheric feedbacks and are further coupled with climate models. This is done by considering the effects of water demand on the dynamics of land-surface variables and updating the surface boundary conditions in climate models (Verseghy, 1991, 2000; Verseghy et al., 1993). Online applications are also termed in the LSM community as coupled land-atmospheric simulations (e.g., Entekhabi and Eagleson, 1989; Noilhan and Planton, 1989) and are more computationally demanding compared to offline simulations. While offline models include both LSMs and GHMs, it should be noted that GHMs cannot be used for online applications as they do not account for the energy balance and therefore cannot fully represent land-atmosphere feedbacks.

The structure of this paper is as follows: in Sect. 2 we highlight the impacts of irrigative and non-irrigative water demands on the terrestrial water cycle and land-atmospheric feedbacks. Sections 3 and 4 provide an overview of available representations of irrigative and non-irrigative demands at larger scales, respectively. In Sect. 5, we briefly explore state-of-the-art applications and highlight current limitations and uncertainties in estimating current and future water demand and associated online and offline impacts. We further discuss current gaps in Sect. 6 and provide some suggestions for future developments. Finally, Sect. 7 summarizes this first 
part of our survey and outlines our main findings with respect to representing human water demand.

\section{Types of human demand and their impacts on the water cycle}

Human water demands can be divided into irrigative and nonirrigative categories. Irrigation is the dominant human water use and has significantly intensified since the 1950s, due to population growth and technological development (Steffen et al., 2011). This has major importance for global food security, as it produces approximately $40 \%$ of the world's food (Abdullah, 2006). Currently, around $25 \%$ of harvested crop area is irrigated (Portmann et al., 2010). This accounts for some $90 \%$ of water consumption at the global scale (Döll et al., 2009; Siebert et al., 2010), which is around $70 \%$ of the total water withdrawals from surface and groundwater resources (Wisser et al., 2008; Gerten and Rost, 2010). Clearly supplying such a large water demand can severely disturb the "natural condition" by decreasing streamflow volume (e.g., Meybeck, 2003; Gaybullaev et al., 2012; Lai et al., 2014) and groundwater levels (e.g., Rodell et al., 2009; Gleeson et al., 2012; Wada et al., 2010, 2012, 2014; Döll et al., 2014). Currently, surface water is the main supplier of global irrigative needs, accounting for $57 \%$ of the total consumptive irrigation use at the global scale (Siebert et al., 2010).

Apart from driving hydrological changes, irrigationinduced changes in soil moisture can affect land surfaceatmosphere feedbacks (see Eltahir, 1998). Pokhrel et al. (2012) showed that increased soil water content through irrigation substantially enhances evapotranspiration, and therefore transforms the surface energy balance. Evapotranspiration due to irrigation leads to cooling of the land surface (e.g., Haddeland et al., 2006; Saeed et al., 2009; Destouni et al., 2010), as well as enhanced cloud cover and chance of convective precipitation (e.g., Moore and Rojstaczer, 2001; Douglas et al., 2009; Harding and Snyder, 2012a, b; Qian et al., 2013). Irrigation may also alter regional circulation patterns due to temperature difference between irrigated areas and neighboring regions (e.g., DeAngelis et al., 2010; Wei et al., 2013). Over highly irrigated regions, this can mask important climate change signals. Gerten et al. (2011), for instance, showed that the irrigation in South Asia has offset the increasing temperature in the region.

Non-irrigative water demands include municipal and industrial uses, energy-related withdrawals, other agricultural uses, such as livestock, as well as designated environmental water uses, which can be an important constraint on water management. Non-irrigative demands contribute a lesser proportion to total human water use at the global scale. This proportion, however, has significant spatial variability (Vassolo and Döll, 2005; Flörke et al., 2013) as regional differences in population, income, life style and technological developments can alter the extent of non-irrigative demand signifi- cantly (e.g., Alcamo et al., 2003; Flörke and Alcamo, 2004; Hejazi et al., 2013a). However, while irrigation is predominantly a consumptive water use, only a small portion of the non-irrigative withdrawal is consumptive (e.g., Hanasaki et al., 2013a). Non-irrigative withdrawals, therefore, partially or totally return to surface-water or groundwater systems with varying degrees of time lag. Still, this can considerably perturb the streamflow regime (e.g., Maybeck, 2003; Förster and Lilliestam, 2010). Non-irrigative water demands are currently on a rapid incline due to growing population and industrial development. This can increase water stress in both time and space (Hejazi et al. 2013a, b, c, d). As non-irrigative demands are mainly non-consumptive, they are less likely to change the energy balance and/or perturb the atmospheric moisture condition significantly and therefore they are less relevant to land-atmospheric interactions. However, changing timing of flows can have significant local effects, for example on wetland inundation. Similarly, for some large-scale mining activities in which the extent of water withdrawals is considerable, the associated changes in soil moisture and land cover can be potentially relevant to land-atmospheric feedbacks. To the best of our knowledge, such online considerations for non-irrigative withdrawals have not yet been explored in the literature.

\section{Available representations of irrigative demand in large-scale models}

Irrigation is an important element of water resource management and has been explored more in depth than non-irrigative demands. To simplify our presentation, we classify current representations with respect to the scale (regional vs. global) and/or mode of simulation (offline vs. online). Tables 1 and 2 summarize representative examples of offline simulations at both regional (Table 1) and global (Table 2) scales. Table 3 presents some online examples. In brief, current online applications have mainly been performed at rather fine temporal and spatial resolutions with shorter simulation periods than offline representations. In contrast, a wide spectrum of host models (i.e., large-scale models in which the irrigation algorithm is embedded), as well as forcing and land-use data, has been used in current offline examples (see Tables 1 and 2). Model resolutions in offline applications can vary in time from $1 \mathrm{~h}$ (e.g., Leng et al., 2013) to 1 day (e.g., Haddeland et al., 2007) with a grid size ranging from a few kilometers (e.g., Siebert and Döll, 2010; Nakayama and Shankman, 2013) to a few hundred kilometers (e.g., Gueneau et al., 2012) in space. Moreover, offline irrigation demand calculations have already been performed globally under future climate conditions. 


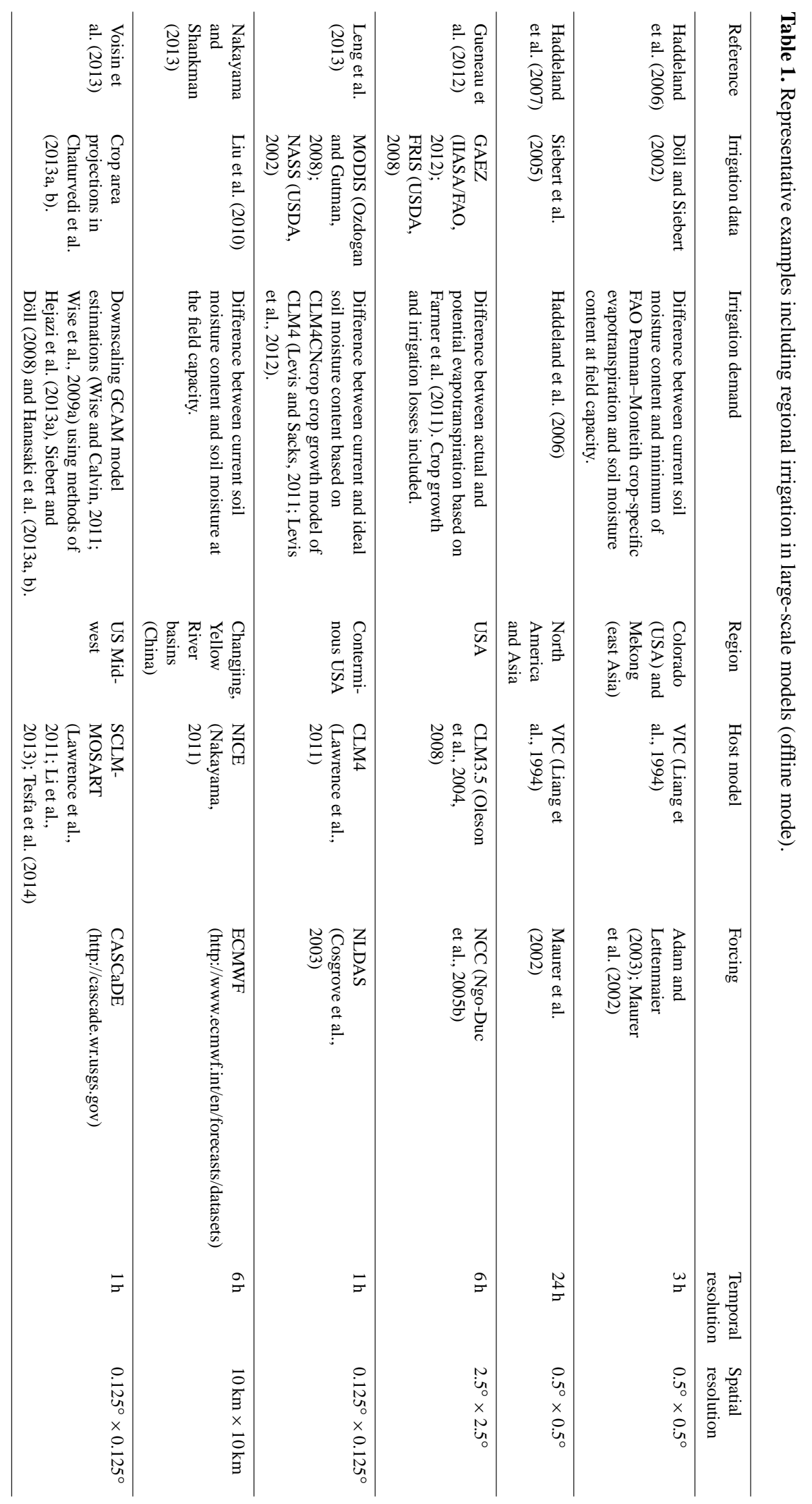




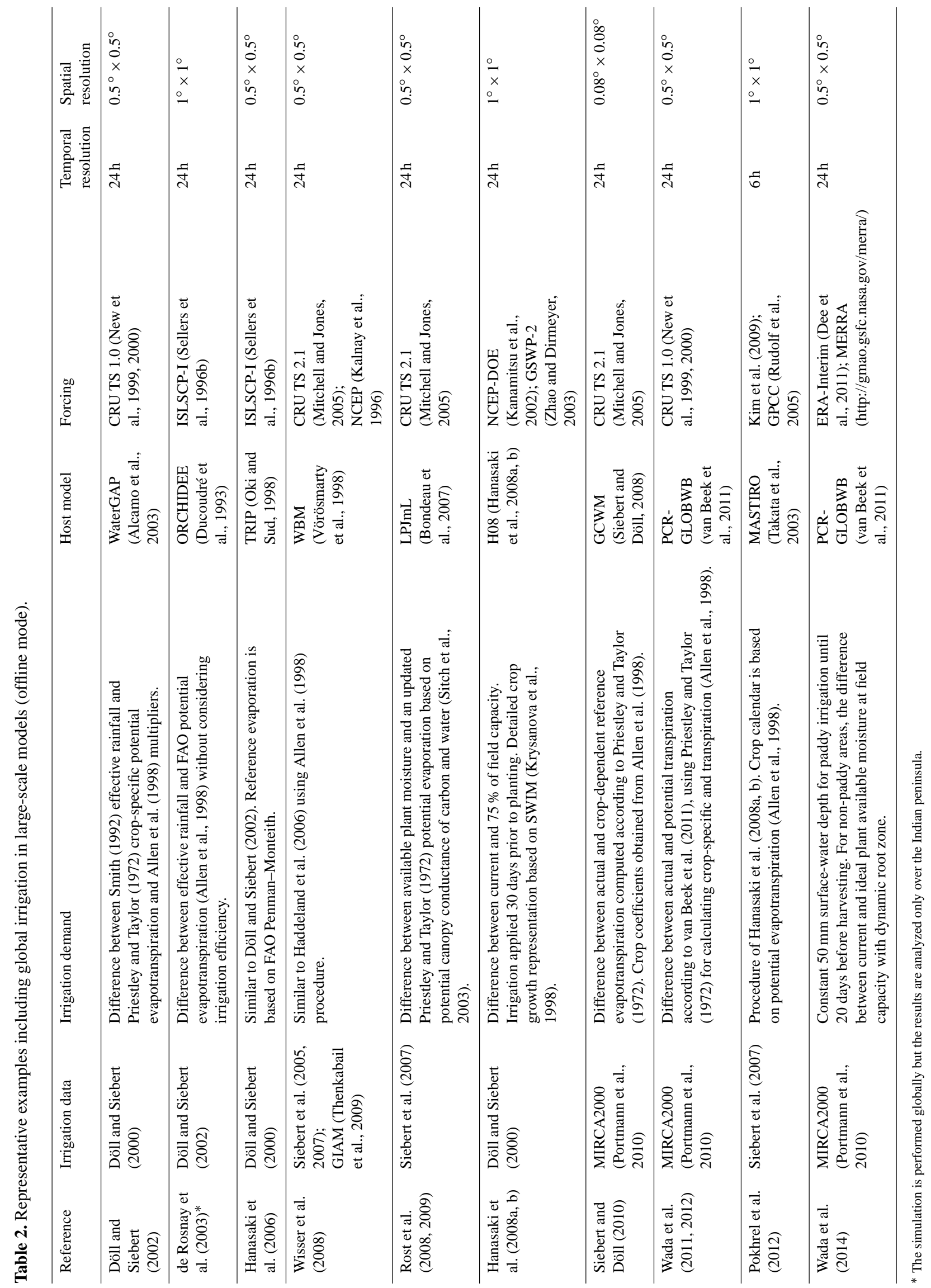




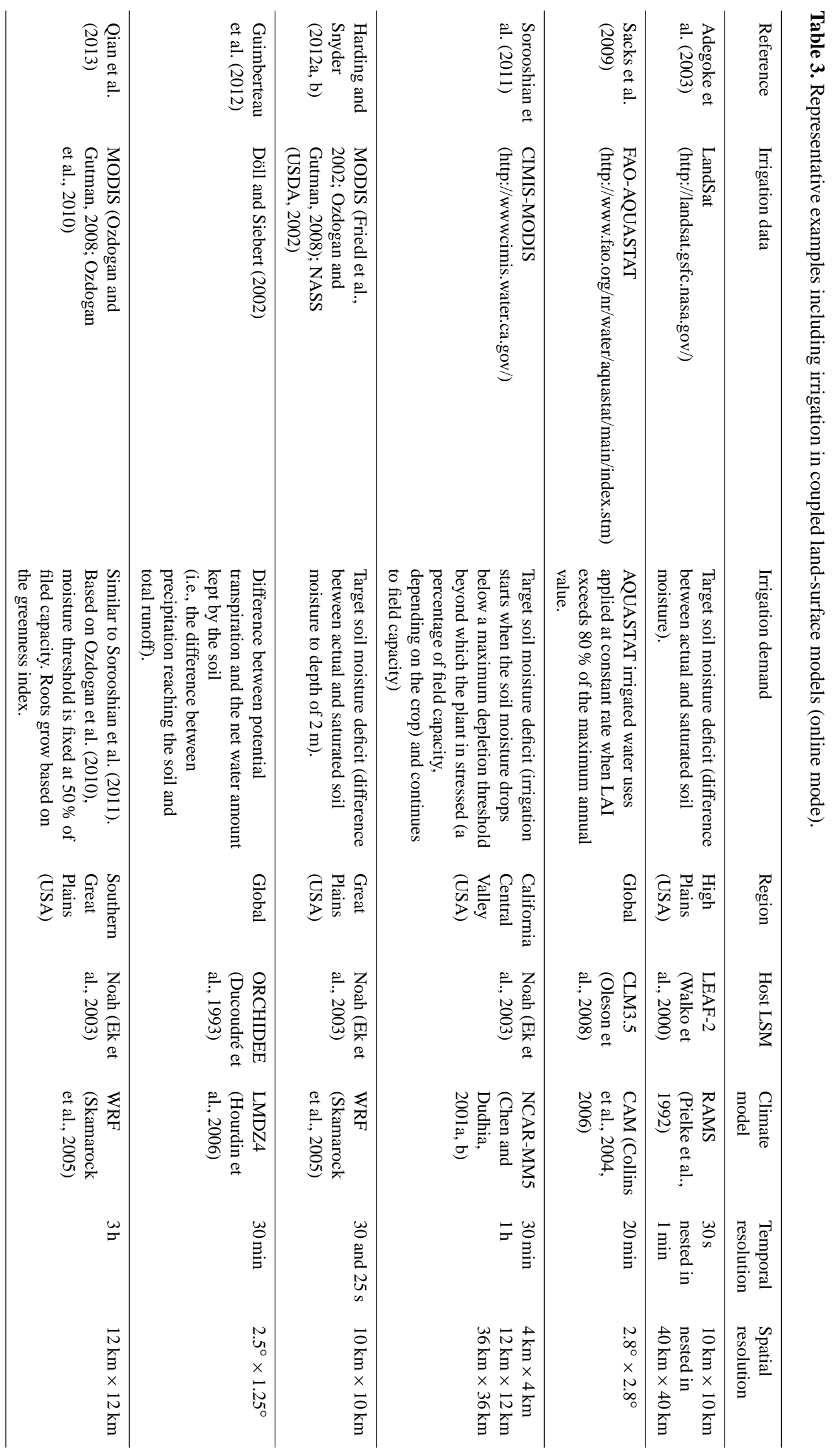




\subsection{Framework and general procedure}

Irrigated lands normally introduce heterogeneity into the computational grids of LSMs and GHMs. Such sub-grid heterogeneity can be represented as an additional "tile", similar to forested land, bare soil and snow cover (Polcher et al., 2011). Essentially, irrigation algorithms are required to estimate the irrigation demand, and accordingly irrigative water use, at the grid scale. Here we refer to the irrigation demand as the water required for ideal crop growth in addition to the available water from precipitation. To simulate the grid-based irrigation demand, crop type and the extent of irrigated regions and growing seasons should be first identified. The location and area of irrigation districts and the associated crop types can be extracted from regional and global data sets (e.g., USDA, 2002, 2008; Siebert et al., 2005, 2007; Portmann et al., 2010) and/or remotely sensed data (e.g., Adegoke et al., 2003; Qian et al., 2013). There are two general approaches for identifying growing seasons. The choice of these options depends on the level of detail in the host model. In simpler models, where no energy-balance calculation is available (i.e., GHMs), crops can grow when and where simple temperature- and precipitation-based criteria are met (e.g., Döll and Siebert, 2002). In more detailed models (i.e., LSMs) the optimal growing season can be identified based on biophysical conditions of crop growth and/or soil water, canopy and energy balance conditions to estimate the cropping period that is necessary to obtain mature and optimal plant biomass (e.g., Rost et al., 2008; Pokhrel et al., 2012). Both approaches are subject to uncertainty. On one hand, models with fixed crop calendars ignore inter-annual variability in growing seasons. On the other hand, even models with fully dynamic crop growth algorithms may misrepresent the seasonality. After the growing season is identified, the irrigation demands (and under some assumptions, actual irrigation withdrawals) at each simulation time step can be calculated. A variety of top-down and bottom-up procedures are available for calculating the irrigation demand in large-scale models and are reviewed further below. If the irrigation demand is completely fulfilled, then the actual evapo(transpi)ration would be equal to crop-specific evapo(transpi)ration under standard conditions (see Allen et al., 1998). In offline applications, the irrigation rate can perturb soil moisture content, evaporation, deep percolation and runoff in irrigated tiles (e.g., Hanasaki et al., 2008a, b; Wada et al., 2011, 2012, 2014). In online applications, the vertical vapor and heat fluxes need also to be considered. The total fluxes for each grid can be then calculated as the sum of the flux contributions from irrigated and non-irrigated portions of the grid (e.g., Haddeland et al., 2006; Pokhrel et al., 2012), and can be further introduced to climate models as coupled surface boundary conditions (e.g., Sorooshian et al., 2011; Harding and Snyder, 2012a, b).

\subsection{Top-down algorithms for calculating irrigation demand}

In top-down approaches, the irrigation demand is not directly calculated, but estimated based on downscaling information available at coarser scales, often at national or geopolitical scales. Such information is based on census-based inventories (e.g., Sacks et al., 2009) or socio-economic model outputs (e.g., Voisin et al., 2013). Top-down approaches are highly influenced by the availability of global data on water use, such as FAO's Information System on Water and Agriculture (AQUASTAT; http://www.fao.org/nr/water/aquastat/ main/index.stm), which provides annual inventory data on national (and in some cases also sub-national) scales, and has been further extended to include socio-economic model outputs. An example of such a model is the Global Change Assessment Model (GCAM; Wise et al., 2009a, b; Wise and Calvin 2011), which estimates agricultural production based on socio-economic variables, from which the irrigation water use is indirectly calculated using the water required for each crop per unit of land. Downscaling is performed mainly using land-use, technological and/or socio-economic proxies. There are various sources of uncertainty associated with top-down algorithms. First, both inventory and model-based products have major limitations due to their spatial and temporal scales as irrigation practices are highly variable within a country and a typical year. Moreover, the quality of both census and model-based products is poor. For instance, there are inconsistencies between census data and data quality varies from country to country (see Portman et al., 2010, for a detailed discussion). Also, socio-economic models widely ignore water availability constraints (Hejazi et al., 2013d). As a result, calculation of irrigation demand is mainly pursued through bottom-up schemes.

\subsection{Bottom-up algorithms for calculating irrigation demand}

In contrast to top-down schemes, bottom-up approaches estimate the irrigation demand directly at the grid scale by mimicking the optimal crop growth for irrigated tiles. Despite major limitations due to the heterogeneity in soil and crops, bottom-up algorithms have been widely used in the literature. These algorithms include a range of modeling assumptions; however, they are all centered around estimation of an ideal crop water requirement, i.e., where there is no water deficit. This requirement is based on estimation of "potential evapo(transpi)ration", which characterizes the atmospheric moisture deficit (Hobbins et al., 2008). There are multiple approaches to estimate the potential evapo(transpi)ration, and the estimates obtained may vary considerably. LSMs typically include detailed energy balance calculations and resolve the diurnal cycle; therefore, they can directly calculate potential and actual evaporations (see Milly, 1992; BarellaOrtiz et al., 2013, for a detailed description). Alternative ap- 
proaches adopt a variety of methods, and are heavily influenced by FAO's guidelines for calculating irrigation water requirements (see Allen et al., 1998). These approaches are mainly used in GHMs, where the evapotranspiration is calculated for a reference crop and corrected as a function of crop type and development stage using a set of empirical coefficients. Various methods are used to characterize the reference evapotranspiration, such as FAO Penman-Monteith (Allen et al., 1998), Priestley and Taylor (1972) and modified Hargreaves (Farmer et al., 2011) to name a few (see McKenney and Rosenberg, 1993, for more examples). The choice of appropriate formulation for reference evapotranspiration is rather arbitrary and depends largely on the data availability as well as the level of detail supported in the host model. It should be noted that, due to the difference in estimation of evaporation, incorporating FAO's guidelines for estimation irrigation demand in LSMs can introduce inconsistencies with the evaporation estimated by the model at various timescales, particularly over dry regions where the irrigation is likely to occur (Polcher, 2014).

Here we briefly explain the currently available bottom-up algorithms, from the more simple to the more comprehensive algorithms, and highlight their strengths and weaknesses.

In the most simple bottom-up representations, the irrigation demand at every time step is the water required to bring the soil moisture at the root zone to saturation (e.g., Lobell et al., 2006; Harding and Snyder, 2012a, b), which describes an extreme demand condition and clearly overestimates the actual irrigation water requirement (Sacks et al., 2009). In a more realistic but still naïve representation, the soil moisture requirement during the growing season is considered to be the field capacity (e.g., Nakayama and Shankman, 2013); therefore, the irrigation water need is the water required to bring the soil moisture to field capacity. The description of the irrigation demand based on the field capacity can also overestimate the actual water requirements, as the evaporation often reaches potential level before the soil reaches field capacity. The threshold at which the evaporation reaches potential evaporation is crop-dependent, but often considered as a constant value in large-scale models. As an offline example, Hanasaki et al. (2008a) assumed that paddy and nonpaddy crops require soil moisture content of 100 or $75 \%$ of the field capacity at the root zone with constant depth at the global scale. Yoshikawa et al. (2014) later updated the assumption for non-paddy soil moisture requirement and used $60 \%$ of field capacity, referring to the requirement for wheat. This is again rather unrealistic as (1) by assuming a constant percentage of the field capacity for all crop types, the diversity in crop water requirement is ignored; and (2) a constant root zone depth at the global scale can result in misestimating the irrigation demand. There are attempts to address these limitations. For instance, Sorooshian et al. (2011) assumed that the required soil moisture content can change for each grid based on the dominant crop. Leng et al. (2013) and Qian et al. (2013) implemented root growth in their irrigation de- mand algorithm to avoid overestimation of demand due to a constant root zone. It should be noted that calculating the root growth is also subject to uncertainty; however, associated limitations remain beyond the scope of this paper.

More realistic definitions of irrigation water demand are based on the difference between the crop-dependent potential evapotranspiration and available crop water. This definition has been widely used in global irrigation demand projections (see Table 2). In earlier examples (e.g., Döll and Siebert, 2002; de Rosnay et al., 2003), crop development is described by constant monthly multipliers for potential evapotranspiration and the effective rainfall is used as a surrogate for available crop water. In more advanced algorithms, the correction factors are considered as functions of daily climate, stage of vegetation and root growth. Moreover, actual evapotranspiration or soil moisture content can be used instead of effective rainfall (Haddeland et al., 2006, 2007; Gueneau et al., 2012). There are two key limitations associated with this approach to simulation of irrigation demands. First, FAO's definition of irrigation water requirement considers both transpiration from crop and evaporation from soil. It has been noted that this quantification may result in overestimating the irrigation demand and may not properly represent the dynamics of vegetation (Polcher et al., 2011). Second, it is assumed that crop growth is a function of water availability only; therefore, the effects of other drivers such as $\mathrm{CO}_{2}$ on photosynthesis are wholly ignored.

Some efforts try to overcome these limitations by defining irrigation demand based on potential transpiration instead of potential evapotranspiration (e.g., Wada et al., 2011, 2012), in conjunction with models that have more comprehensive vegetation schemes. Potential transpiration is the transpiration that would occur if the crop is not water stressed. Potential transpiration takes into account $\mathrm{CO}_{2}$ fertilization effects and can represent the adaptation of the plants to climatic conditions and/or crop growth cycles, if the host model is equipped with relevant calculations (Guimberteau et al., 2012); therefore, this approach is mainly used in LSMs with detailed consideration of vegetation growth. As an example, Rost et al. (2008) coupled a transpiration deficit algorithm with the Lund-Potsdam-Jena managed Land scheme (LPJmL; Bondeau et al., 2007), which has a detailed vegetation growth module based on carbon and water availability (see Sitch et al., 2003; Gerten et al., 2004). The crop water limitation was calculated based on the atmospheric water deficit, soil moisture, plant hydraulic states as well as the $\mathrm{CO}_{2}$ effects. Considering the effects of both carbon and water in vegetation can provide a basis for explicit linkage between $\mathrm{CO}_{2}$ emission, crop growth and irrigation water requirement. This would be important for future predictions under increasing $\mathrm{CO}_{2}$ effects. Moreover, some recent simulations showed that the irrigation requirement changes if a dynamic growth model is used; and this can improve the partitioning of latent heat flux, which is relevant to online applications (e.g., Lu, 2013). Nonetheless, it should be noted that the success of po- 
tential transpiration algorithm depends strongly on the way various tiles are treated at the grid scale. Normally, LSMs can define multiple crops at the grid scale and can distinguish the various water needs across different tiles within a grid. If potential transpiration is implemented consistently with sub-grid soil moisture divisions, then the water taken from the irrigated tiles optimizes photosynthesis and is only evaporated by the crops and not used by other surface types (e.g., bare soil, non-irrigated crops). In contrast, if all tiles share the same soil moisture reservoir at the grid scale, irrigation will increase the soil moisture and evaporation and therefore reduce water stress over the whole grid.

\subsection{Projection of irrigative demand}

From water and food security perspectives, particularly under various global change scenarios, it is crucial to investigate future irrigation demand and assess various possibilities for irrigation deficit. Climate model projections under IPCC emission scenarios (IPCC, 2000) have been widely used to force bottom-up irrigation demand algorithms (e.g., Arnell, 1999; Wada et al., 2013; Rosenzweig et al., 2014). Efforts have been also made to include intermediate socioeconomic scenarios that can be matched to current climate change scenarios (see, e.g., Arnell, 2004; Fischer et al., 2007; Alcamo et al., 2007). For irrigation, intermediate scenarios describe changes in irrigated areas, irrigation efficiency and crop type, using empirical approaches. For example, Hanasaki et al. (2013a) recently proposed intermediate scenarios based on newly developed Shared Socio-economic Pathways (SSPs; Kriegler et al., 2012; see also Moss et al., 2010), which are consistent with Representative Concentration Pathways (RCPs; Meinshausen et al., 2011; K. E. Taylor et al., 2012). Constructing intermediate scenarios using empirical procedures, however, is uncertain as mechanisms that link irrigation expansion to socio-economic factors are not fully known and current empirical relationships can contain large uncertainties. More dynamic linkage between irrigation expansion and socio-economic drivers can be provided by coupled socio-economy-energy-carbon models. One emerging model of such a kind is GCAM, which has been recently implemented for simulating the future expansions in irrigation areas and demands (Hejazi et al., 2013b, c, d) as well as policy implications for irrigation water requirements (e.g., Chaturvedi et al., 2013a, b). Although these models can represent the dynamic effects of various drivers on irrigation, they remain uncertain as their simulations are rather coarse and do not incorporate water availability constraints. There are emerging efforts to avoid this limitation by linking the irrigation demand to climate, economy and water management constraints. This can result in prediction of regions in which irrigation can be developed and sustained considering changing climate, water availability, water price and water management infrastructure (see Nassopoulos et al., 2008,
2012). Such approaches however have not been applied at larger regional and global scales.

\section{Available representations of non-irrigative demand}

\subsection{Forms and drivers of non-irrigative demand}

Non-irrigative water demands relate to a wide range of environmental, municipal, industrial and energy-related uses, as well as other agricultural water needs (e.g., livestock), and include both consumptive and non-consumptive withdrawals. Among these, livestock water demand is assumed fully consumptive, and can be estimated by livestock number and demand per livestock head (e.g., Wada et al., 2011; Strzepek et al., 2012b; Hejazi et al., 2013d). Wada et al. (2014) made a further improvement by estimating daily livestock requirements at $0.5^{\circ} \times 0.5^{\circ}$ spatial resolution using livestock data of Steinfeld et al. (2006). Daily demand was considered as a function of daily temperature.

In contrast to livestock water demand, environmental flow needs can be considered as a fully non-consumptive need, required to protect rivers' health and aquatic life. Considering the extent of environmental degradation at the global scale, accounting for environmental flow needs becomes more and more relevant and should be considered as an integral part of water resource management at larger scales. Tharme (2003) made an extensive review of available methodologies for estimating environmental flow needs and identified more than 200 methodologies based on various hydrological, hydraulic rating, habitat simulation and holistic guidelines at the river basin scale. There are also some recent trends to involve scientists, water-resource managers and stakeholders to analyze available hydrological information and convert them into ecologically based and socially acceptable goals for estimating the environmental flow needs (see Poff et al., 2009). Such procedures however are widely dependent on the availability of relevant information and, therefore, cannot be easily implemented in large-scale models. Currently, implementation of environmental flow needs in large-scale models remains rather limited and simplistic and these needs are often calculated based on generic rules. For instance, Smakhtin et al. (2004) assigned thresholds for fair $\left(Q_{90}\right)$, natural $\left(Q_{50}\right)$ and good $\left(Q_{75}\right)$ natural flow conditions. Shirakawa (2004, 2005, referenced from Hanasaki et al., 2008a) distinguished between two factors, i.e., minimum and perturbation flow requirements, which can also accommodate transient streamflow conditions. Currently, the perturbation flow requirements are often ignored in large-scale models and the environmental needs are estimated as a minimum flow threshold (often $Q_{90}$ or $10 \%$ of mean annual), which should be maintained in the river reaches (e.g., Hanasaki et al., 2008a; Döll et al., 2009; Strzepek et al., 2010, 2012b; Blanc et al., 2013). Other rules have been also suggested. For instance, Haddeland et al. (2006) considered a 7-day consecutive low flow 
with a 10-year recurrence period as the environmental flow requirement. Although these rules are easily implementable for larger regions and global scales, they widely ignore natural system complexity and the local policy context and can contribute to misunderstanding of the extent of environmental water stress (Arthington et al., 2006).

At this stage of model development, municipal, industrial and energy-related water demands are considered as the most dominant forms of non-irrigative uses. These demands are estimated using complex functions of socio-economic and technological factors, with high variability in time and space. Population is the most significant factor driving these withdrawals (e.g., Alcamo et al., 2003; Hanasaki et al., 2008a; Wada et al., 2014). National gross domestic product (GDP) is also a strong factor (e.g., Gleick, 1996; Cole, 2004; Wada et al., 2011). Although higher GDP may trigger more municipal water use per capita (Alcamo et al., 2007), Hughes et al. (2010) showed that, in general, water uses per capita are greater in developing than developed countries due to low-tech water delivery and industrialization. Strzepek et al. (2010) argued that industrial water use increases with the level of resource industry and decreases when a country moves toward the service sector. Industrial technology is another important factor for non-irrigative use as the extent of both consumptive and non-consumptive uses can significantly change based on the type of technology. Macknick et al. (2011), for instance, provided estimates of total water withdrawals and consumption for most electricity generation technologies within the US. Comparing to recirculating cooling technology, they noted that once-through cooling requires 10 to 100 times more water withdrawal per unit of electric generation. However, the latter consumes less than half of the water consumed by recirculating cooling technology. Climate can be another important factor controlling both consumptive and non-consumptive withdrawals (e.g., Wada et al., 2011, 2014; Hejazi et al., 2013a; Voisin et al., 2013), but has often been ignored as an explicit driver of nonirrigative water demand.

\subsection{Top-down algorithms for estimation of grid-based non-irrigative withdrawals}

Unlike irrigation demand, top-down approaches have been widely used for non-irrigative withdrawals to transfer national or geopolitical data to basin or grid scales. Various downscaling procedures have been suggested, based on different proxies (see Table 4). These top-down schemes are heavily influenced by the availability of national and global data sets and the downscaling algorithms within the Water - Global Assessment and Prognosis scheme, which is a global water budget and use model (WaterGAP; Alcamo et al., 1997, 2003, 2007). Currently, the availability of different global information sources has provided the opportunity to generate gridded products from different sources. As an example, Hanasaki et al. (2008a) merged the FAO-AQUASTAT data with population distributions and national boundary information from Columbia University (CIAT, 2005) and the consumptive ratios of Shiklomanov (2000) to come up with gridded industrial and municipal water withdrawals and uses at the global scale. More detailed information on various industrial uses resulted in breaking down the industrial withdrawals into their components. For instance, Vassolo and Döll (2005) distinguished between industrial water uses related to thermoelectric power generation and manufacturing production. Temporal disaggregation of annual withdrawals, however, has received much less attention. Recently Wada et al. (2011, 2014) and Voisin et al. (2013) developed simple algorithms to disaggregate annual data to monthly and daily estimates (see Table 5).

\subsection{Projection of non-irrigative demand}

Characterizing the past and future evolution of non-irrigative demands is required to understand the mechanisms controlling water use and water allocation. Current projections have coarse temporal and spatial resolution and describe non-irrigative demands as functions of socio-economic and technological developments (e.g., Davies et al., 2013; Blanc et al., 2013; Hejazi et al., 2013b, d; Voisin et al., 2013). These changes can be characterized by intermediate socioeconomic and technological scenarios, as briefly explained above for irrigation expansion (see Sect. 3.4). The projected demands can be further downscaled using various proxy variables, as explained in Sect. 4.2. Table 6 summarizes some representative efforts, which can be classified as explicit and implicit algorithms. In explicit algorithms, changes in water withdrawals are directly described as functions of changes in socio-economy, technology and water price using simple parametric structures (e.g., Strzepek et al., 2012b; Flörke et al., 2013; Hanasaki et al., 2013a; Hejazi et al., 2013a). The parameters can be assigned using the available global and regional data. In implicit procedures, first the production (or population) is estimated based on integrated economy and population models or prescribed scenarios. By considering the amount of water withdrawal per unit of production (or population) and accounting for technological and/or socioeconomic shifts, water withdrawals are consequently projected.

\section{State of large-scale modeling applications}

The algorithms reviewed in Sects. 3 and 4 have had a wide range of online and offline applications. In comparison to offline applications, online simulations are still at a relatively early stage of development; they typically only include irrigation, mainly implemented at regional scale and under current conditions, and present rather contradictory results. Offline applications in contrast include both irrigative and nonirrigative demands, performed under current and future con- 
Table 4. Representative examples calculating grid-based non-irrigative demands using downscaling of coarse-scale estimates.

\begin{tabular}{|c|c|c|c|c|}
\hline Reference & $\begin{array}{l}\text { Estimated } \\
\text { demand }\end{array}$ & Downscaling procedure & Data support & $\begin{array}{l}\text { Targeted } \\
\text { resolution }\end{array}$ \\
\hline \multirow[t]{2}{*}{$\begin{array}{l}\text { Alcamo et al. } \\
(2003)\end{array}$} & Domestic & $\begin{array}{l}\text { Distributing country-level } \\
\text { withdrawals based on population, } \\
\text { ratio of rural to urban population } \\
\text { (constant for each country) and } \\
\text { percentage of population with access } \\
\text { to drinking water }\end{array}$ & $\begin{array}{l}\text { Population (van Woerden et } \\
\text { al., 1995); access to } \\
\text { drinking water (WRI, 1998) }\end{array}$ & \multirow[t]{2}{*}{$\begin{array}{l}0.5^{\circ} \times 0.5^{\circ} \\
(\text { global })\end{array}$} \\
\hline & Industrial & $\begin{array}{l}\text { Downscaling countywide industrial } \\
\text { withdrawals based on proportion of } \\
\text { urban population }\end{array}$ & $\begin{array}{l}\text { Population (van Woerden et } \\
\text { al., 1995) }\end{array}$ & \\
\hline \multirow[t]{2}{*}{$\begin{array}{l}\text { Vassolo } \\
\text { and Döll } \\
(2005)\end{array}$} & $\begin{array}{l}\text { Thermoelectric } \\
\text { cooling }\end{array}$ & $\begin{array}{l}\text { Calculating the gridded data for } \\
\text { power production based on } \\
\text { downscaling global estimates. } \\
\text { Allocating constant flow to each unit } \\
\text { of production according to type of } \\
\text { cooling system. }\end{array}$ & $\begin{array}{l}\text { World Electric Power Plants } \\
\text { Data Set } \\
\text { (http://www.platts.com) }\end{array}$ & \multirow[t]{2}{*}{$\begin{array}{l}0.5^{\circ} \times 0.5^{\circ} \\
\text { (global) }\end{array}$} \\
\hline & Manufacturing & $\begin{array}{l}\text { Estimating countrywide sectoral } \\
\text { production volumes along with water } \\
\text { intensity for each unit of production } \\
\text { in each sector. Downscaling total } \\
\text { demand to the grid scale based on } \\
\text { city nighttime light. }\end{array}$ & $\begin{array}{l}\text { Industrial production } \\
\text { volumes (UN, 1997; CIA, } \\
\text { 2001); sectoral intensity } \\
\text { (Shiklomanov, 2000; WRI, } \\
\text { 2000); night city light } \\
\text { pollution (US Air Force, } \\
\text { www.ngdc.noaa.gov/dmsp) }\end{array}$ & \\
\hline $\begin{array}{l}\text { Hanaskai et } \\
\text { al. }(2008 \mathrm{a})\end{array}$ & $\begin{array}{l}\text { Domestic and } \\
\text { industrial }\end{array}$ & $\begin{array}{l}\text { Countrywide data downscaled to grid } \\
\text { scale by weighting population and } \\
\text { national boundary information, } \\
\text { further converted to water } \\
\text { consumption estimates. }\end{array}$ & $\begin{array}{l}\text { AQUASTAT countrywide } \\
\text { withdrawals, population and } \\
\text { national boundaries (CIAT, } \\
\text { 2005); ratio of consumption } \\
\text { to withdrawal } \\
\text { (Shiklomanov, 2000). }\end{array}$ & $\begin{array}{l}1^{\circ} \times 1^{\circ} \\
(\text { global })\end{array}$ \\
\hline $\begin{array}{l}\text { Hejazi et } \\
\text { al. }(2013 b)\end{array}$ & $\begin{array}{l}\text { Municipal and } \\
\text { industrial }\end{array}$ & $\begin{array}{l}\text { Demand estimates of GCAM model } \\
\text { (http://wiki.umd.edu/gcam) } \\
\text { downscaled as a function of } \\
\text { population. Population density } \\
\text { assumed static in time. }\end{array}$ & $\begin{array}{l}\text { Global population density } \\
\text { data based on WWDR-II } \\
\text { and methodology of Wada } \\
\text { et al. }(2011,2013 a)\end{array}$ & $\begin{array}{l}0.5^{\circ} \times 0.5^{\circ} \\
\text { (global) }\end{array}$ \\
\hline
\end{tabular}

Table 5. Representative examples for disaggregating annual non-irrigative demand into monthly estimates.

\begin{tabular}{llll}
\hline Reference & $\begin{array}{l}\text { Estimated } \\
\text { demand }\end{array}$ & Disaggregation procedure & Data support \\
\hline $\begin{array}{l}\text { Wada et al. } \\
(2011,2014)\end{array}$ & $\begin{array}{l}\text { Municipal } \\
\text { and livestock }\end{array}$ & $\begin{array}{l}\text { Downscaling annual demand to monthly fluctuations } \\
\text { as a function of temperature }\end{array}$ & $\begin{array}{l}\text { CRU (New et al., 1999, } \\
\text { 2000) }\end{array}$ \\
\hline $\begin{array}{l}\text { Voisin et al. } \\
(2013)\end{array}$ & Electrical & $\begin{array}{l}\text { Dividing electrical use into industry, transportation and } \\
\text { building sectors. Assuming uniform distribution for } \\
\text { industry and transportation uses and capturing the } \\
\text { monthly fluctuations in building use based on } \\
\text { heating/cooling degree days. }\end{array}$ & $\begin{array}{l}\text { CASCaDE } \\
\text { (httplcascade.wr.usgs.gov) }\end{array}$ \\
\hline
\end{tabular}




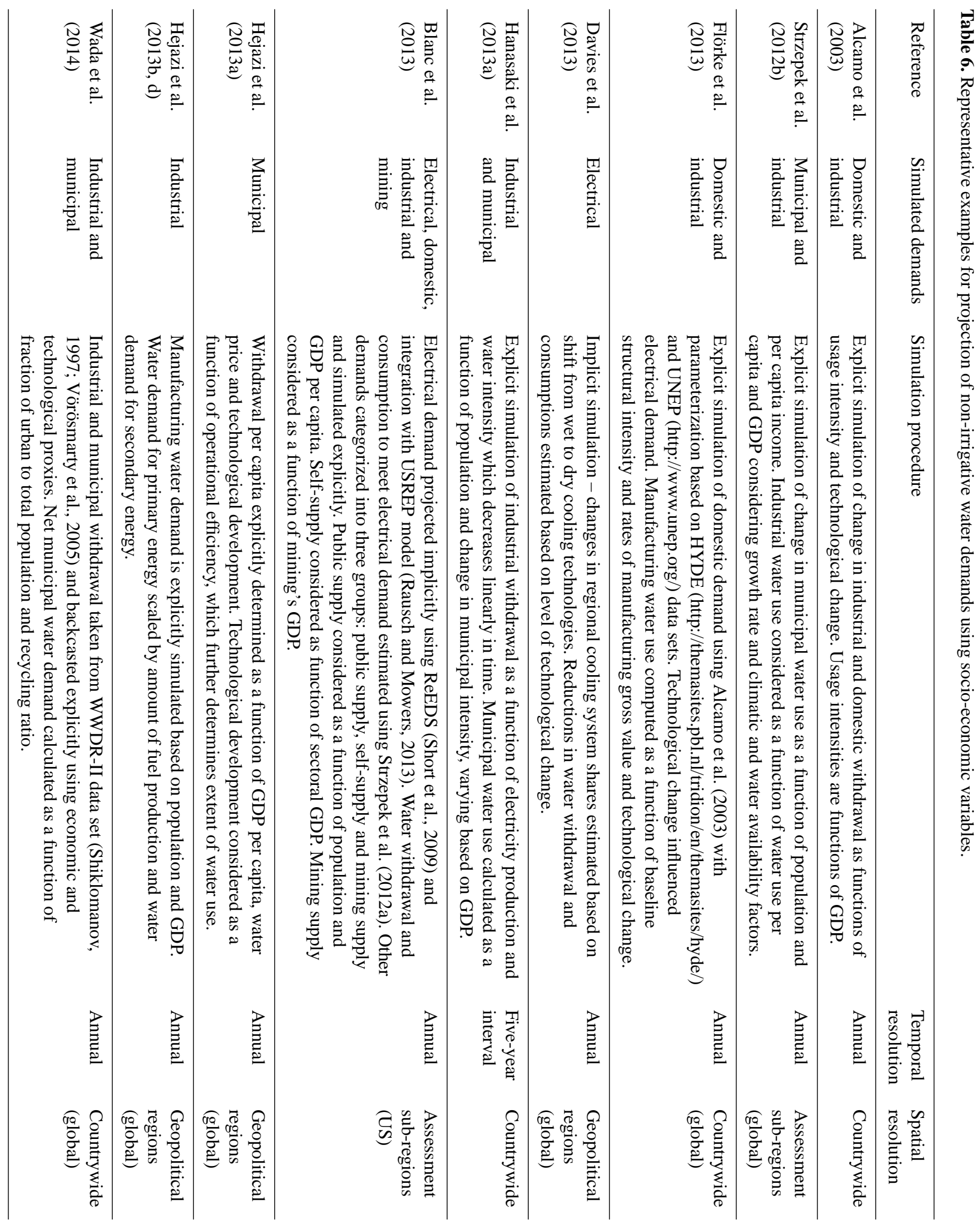


ditions, and provide relatively more consistent results. Here, we briefly summarize recent applications and highlight the limitations in current simulations.

\subsection{Online representation}

Recent studies have shown that including irrigation in coupled land-surface schemes can generally improve climate simulations. With respect to regional temperature, for instance, Saeed et al. (2009) showed that representing irrigation activities over northwestern India and Pakistan can reduce climate model simulation bias by $5^{\circ} \mathrm{K}$. It should be noted, however, that there are still large disagreements in quantifying the effects of irrigation on regional and global temperature (see, e.g., Boucher et al., 2004 vs. Lobell et al., 2006), mainly attributed to the difference in the implemented irrigation demand calculations. Sacks et al. (2009) tried to overcome the limitations in demand algorithms by downscaling the AQUASTAT irrigative water use data to the grid scale. They concluded that irrigation has significant importance for regional temperature, but at global scale the temperature cooling in some regions due to irrigation is canceled by temperature warming in some other areas due to climate, land-cover and circulation changes. There are, however, some limitations in their study, as the irrigation demand did not vary between years and they applied irrigation only when the LAI is around $80 \%$ of the annual LAI. These assumptions can result in large uncertainty.

Irrigation-induced precipitation has been studied for quite some time and irrigation has been shown to have a significant effect on local and regional precipitation patterns (e.g., Barnston and Schickedanz, 1984; Moore and Rojstaczer, 2001). For instance despite regional decline, Tuinenberg et al. (2011) found a positive precipitation trend in climate stations located in the irrigated regions of the southern Asia. Lucas-Picher et al. (2011) tested four climate models and argued that lack of representation of irrigation is the main reason for precipitation bias over the Indian monsoon area. Guimberteau et al. (2012) showed that irrigation can also affect the onset of mean monsoon date over the Indian peninsula, leading to a significant decrease in precipitation during May to July. Nonetheless, there are still large disagreements in (1) identifying the dominant mechanisms that drive the irrigation-induced precipitation; and (2) estimating the amount and spatial extension of change in precipitation. DeAngelis et al. (2010) noted that the growing season precipitation increased in the Great Plains of the US during the 20th century as a result of intensive irrigation. Using vapor tracking analysis, they indicated that evaporation from irrigated lands adds to downwind precipitation, which increases as the evaporation increases. Harding and Snyder (2012a, b), however, noted that the extent of effects on precipitation also depend on the antecedent soil moisture. They argued that, in low soil moisture conditions, further irrigation can result in suppression of regional precipitation. Guimberteau et al. (2012) argued that these contrasting results might be due to differences in local moisture, where the irrigation is applied. Based on a 30-year simulation, they showed an increase in summer precipitation over the arid western region of the Mississippi River basin in association with enhanced evapotranspiration. However, a decrease in precipitation was identified over the wet eastern part of the basin. These results, however, are based on only one set of models and the coarse grid resolution might degrade the quality of simulations - see the discussion below. With respect to the scale of disturbance, Sorooshian et al. (2011) showed that irrigation over California's Central Valley significantly decreases local temperature and increases local precipitation; however, they argued that the effects of irrigation do not expand far from the place where irrigation takes place. In contrast, Lo and Famiglietti (2013) argued that irrigation in California's Central Valley intensifies the water cycle in the southwestern US and can increase the flow in the Colorado River.

There are two main limitations associated with available simulations of irrigation-induced rainfall discussed above. First, in most of the online studies, water availability is not a constraint. As a result, the water balance is not closed and they simply analyze whether evaporation increase can enhance atmospheric moisture convergence or not. This can be considered as a major limitation as the available water can control the extent of irrigation (and consequently evaporation) and stabilize the associated feedback processes. Second, it is known that sharp landscape contrasts (i.e., transitions between wet and cool as well as dry and hot areas) critically affect rainfall formation (e.g., Taylor 2009; C. M. Taylor et al., 2012). Although irrigation can create such transitions due to enhanced evaporation and decreased surface temperature, current LSMs are generally unable to generate the atmospheric perturbations due to these transitions (Polcher, 2014). Due to these limitations, the results of current sensitivity analyses should be considered with caution.

Online simulations under future climate change are limited and have been performed mainly at regional scales. Gerten et al. (2011) used a nested regional climate model to dynamically downscale the future simulations of a global climate model over southern Asia and considered two modes of simulation: with or without irrigation. They concluded that including irrigation can result in roughly half of the temperature increase predicted without representing irrigation. With respect to future precipitation, simulation with and without irrigation both showed a decrease in precipitation over northern India and increase in precipitation over the southern peninsula; the latter was enhanced with irrigation. They noted that the increase in precipitation cannot be seen if the global-scale simulations are not dynamically downscaled. This highlights the importance of including irrigation schemes in regional climate models for dynamic downscaling of future climate change scenarios.

In summary, despite current limitations and differences in the host climate and LSM models, irrigation demand al- 
gorithms and simulation settings, significant feedback effects are associated with irrigation. Large uncertainties, however, exist in current coupled irrigation-land-surface-climate modeling, which emphasizes the need for more research in this area.

\subsection{Offline representation}

Offline representation of water demands is more common, and a wide variety of GHMs and LSMs in conjunction with different demand algorithms have been used to simulate the dynamics of water demand under both current and future conditions. The available global simulations under current conditions are compared and summarized in Wada et al. (2014) and Chaturvedi et al. (2013a, b) for irrigative demands and in Alcamo et al. (2003) and Hejazi et al. (2013b) for total water consumption. Although incorporating water demand calculations can generally result in more realistic river discharge simulations (see Ngo-Duc et al., 2005a, b, 2007), current simulations exhibit large differences in estimates of water demand and use at countrywide, continental and global scales. This can be referred to the differences in data support, demand calculation schemes and host models see the discussion of Sect. 6 .

Normally, future projections of water demands include more uncertainty than simulation of current conditions as they are also conditioned on uncertain climate futures and/or socio-economic and technological scenarios. Considering future climate projections, with or without considering irrigation expansion, irrigation demand algorithms have mainly projected increase in irrigation demand under climate change scenarios. As an early example, Fischer et al. (2007) estimated irrigation water requirement as a function of both projected irrigated land and climate change from 1990 to 2080. They showed that the impact of climate change on increasing irrigation water requirement could be nearly as large as the changes initiated by socio-economic developments. There are, however, two sets of uncertainty associated with future projections of irrigation demand. First, gridded climate products have significant deficiencies in representing current and future climate, particularly with respect to precipitation (e.g., Lorenz and Kunstmann, 2012; Grey et al., 2013). This can further propagate to estimation of irrigation demand at the sub-grid scale. Second, there are large disagreements between irrigation demand projections with respect to different climate model simulation, irrigation algorithms and host large-scale models. One possible approach to account for these uncertainties would be using a multi-model approach, as recommended by Gosling et al. (2011) and Haddeland et al. $(2011,2014)$ and implemented to some extent by Wada et al. (2013) and Rosenzweig et al. (2014). Based on the latest IPCC climate scenarios (K. E. Taylor et al., 2012), these studies generally concluded that a significant increase in future demand is likely, with possibly 1-month or more shift in the peak irrigation demand in mid-latitude regions
(Wada et al., 2013), but large uncertainties are associated with the predictions (see Rosenzweig et al., 2014). Moreover, both studies noted that $\mathrm{CO}_{2}$ increases might have beneficial effects on crop transpiration efficiency, if other factors are not limiting (see also Gerten et al., 2011; Konzmann et al., 2013). Nonetheless, it still remains unclear whether increased transpiration efficiency is canceled out by increased transpiration due to increasing biomass and plant growth. More studies, therefore, are required in this direction (see Gerten, 2013). This is a context for which LSMs can offer an ideal platform as they have the explicit modules required for considering dynamic interactions of carbon, vegetation and water - see the discussion of Sect. 6.

Similar conclusions were obtained with respect to nonirrigative demands. Alcamo et al. (2007) and Hejazi et al. (2013d) showed that increasing domestic and industrial water uses, if not controlled, can be a major threat for water supply. There are, however, large discrepancies between different projections of non-irrigative demands (Gleick, 2003), in which the divergence between modeling results becomes more highlighted as the projection horizon increases (see Davis et al. (2013) for electrical demand and associated water use). These uncertainties can be referred to limitations in current data availability for supporting robust and reliable projections, differences in socio-economic and technological scenarios, as well as some underlying assumptions in demand calculation algorithms, which can limit their efficiency in future simulations.

As the current global potential for expanding water demand is rather limited (Rost et al., 2009; Gerten and Rost, 2010), adaptation and mitigation strategies are required to moderate human water demands. In such cases prescribed "policy" scenarios can be introduced into large-scale models for impact assessment. Using this approach, it has been shown that mitigation can significantly decrease future global water demand. For example, Hanasaki et al. (2013a) showed approximately 7 -fold and 2.5 -fold variation in industrial and municipal demands, depending on the SSP considered. The effects of mitigation, however, have large regional variation. For irrigative demands, Fischer et al. (2007) showed that some regions may be negatively affected by mitigation actions, which depend on specific combinations of $\mathrm{CO}_{2}$ changes that affect crop water requirement and projected precipitation and temperature changes. Kyle et al. (2013) showed that applying $\mathrm{CO}_{2}$ mitigation policies can result in high deployment of other high-tech solutions for electrical generation (e.g., solar power) that have low water requirements. Hejazi et al. (2013c) further showed that taxation can be an important factor in mitigating the effect of water scarcity by regulating more water efficient options for irrigation. Hejazi et al. (2013a) further showed the possibility of a slight decrease in municipal withdrawals in the year 2100 under a high-tech scenario, despite significant population growth. Davies et al. (2013) showed similar results for electricity water withdrawals if high-tech solutions 
are employed. Large-scale models also showed that promoting international trade can be a strong adaptation option for controlling regional demand, in which water-limited regions can import water-expensive products from other areas (e.g., Siebert and Döll, 2010; Hanasaki et al., 2010; Konar et al., 2013). Assessment of trade scenarios and water footprinting, however, needs detailed tracking of the water cycle (see Chenoweth et al., 2014) and is highly dependent on how reasonable the human demands and production, as well as water availability and water allocation, are described in time and space. Such a level of accuracy is currently not available and therefore the assessments remain widely uncertain.

In summary, current offline projections agree on large impacts of future change in climate, socio-economy and technology on water demands and the importance of adaptation and mitigation strategies for managing future water security threats. Available projections, however, are rather limited and suffer from major sources of uncertainty, which is revealed by large discrepancies between different simulation products under current and future conditions. We now turn to discuss these gaps in more detail and identify the research needs and priorities.

\section{Discussion}

Major gaps remain in the current capability in modeling water demands and understanding their online and offline impacts on the terrestrial water cycle and human livelihoods. These gaps are partially due to inherent complexity in modeling Earth system processes, which is more significant in coupled simulation modes. Apart from various computational barriers, one main challenge in online simulations is the uncertainty associated with coupling land and atmospheric models, as given a unique land-surface boundary condition, the simulations obtained by different climate models can be divergent (Koster et al., 2004; Pitman et al., 2009; Dadson et al., 2013). Another major challenge for coupled irrigationland-surface-climate simulations is the choice of appropriate temporal and spatial resolutions, at which the relevant physical processes and feedbacks between land and atmosphere should be represented and described. Ideally, the optimal modeling resolution should be identified based on physical realism; nonetheless, the choice of resolution in coupled simulations is mainly constrained by computational resources, data availability and the complexity supported by the LSMs. If these are not limiting factors, it has been shown that finer temporal and spatial resolutions can improve online representation of irrigation. For instance, using six different combinations of temporal/spatial resolutions, Sorooshian et al. (2011) concluded that spatial and temporal resolution in coupled irrigation-land-climate models can significantly change both temperature and precipitation simulations over irrigated grids and a fine level of detail is required for representing the physical processes controlling the feedbacks between irrigation and atmosphere. However, these findings remain regionally and seasonally dependent and are closely linked to the level of complexity supported in the considered irrigation parameterization and host model. It should be noted that, by increasing the spatial resolution, more processes need to be included in order to ensure water conservation within the model and that can further complicate the issues related to water availability - see the discussion below. The effects of fine modeling resolution seem to be in general less significant in offline runs, as far as the evaporation calculation is consistent with estimation of crop water requirements and each crop is supplied by a unique moisture reservoir. Compton and Best (2011) conducted offline global simulations and showed that fine spatial resolution has little importance on long-term modeling of evaporation and runoff; however, the temporal resolution does change the mean evaporation/runoff balance. The issues around modeling resolution are explored further in Nazemi and Wheater (2015).

Large uncertainties are also associated with offline human water demand simulations under current and future conditions. Lissner et al. (2012), for instance, noticed significant difference in terms of water demand per capita between the simulated products of WaterGAP and reported AQUASTAT data. These uncertainties are mainly related to (i) available data support, (ii) demand calculation algorithms and (iii) host models. These sources are widely connected and cannot be easily addressed and quantified independently. Here we briefly discuss these sources and propose few directions for future developments.

1. Uncertainty in current data support: primarily, there are considerable uncertainties across the input and forcing data required for executing large-scale models. Generally, large-scale models discussed in this paper are forced and initialized using various data sources that are developed and maintained independently. This results in major inconsistencies, particularly at the grid scale, where it is often the case that information coming from different sources does not match each other (e.g., soil properties do not fit to land use). Typically, modelers fix these issues by applying simple rules or assumptions; however, inconstancies in personal judgments can highly affect the quality of simulations at the local and regional scales (see Bormann et al., 2011, for a local study). Major uncertainties are also associated with the data required for executing demand calculation algorithms. Siebert et al. (2005) noted that even the locations of irrigation districts are uncertain in many regions and sub-grid variability of crops within irrigated areas is not generally available. Wisser et al. (2008) argued that major uncertainties are associated with forcing, irrigation and crop maps, and this can result in large differences between simulations of irrigation water requirement. Another source of data uncertainty is the generally sparse information on irrigation techniques. 
This can be important for understanding the amount of water loss and thus estimating the actual irrigation use and evaporation (see, e.g., Evan and Zaitchik, 2008). The issues around data support apply to non-irrigative demands as well. For the case of water use for electricity generation in the US, Macknick et al. (2011) noted that "federal data sets on water use in power plants have numerous gaps and methodological inconsistencies." Data uncertainty can propagate into structural and parametric identification during model development and can further extend to future projections. The availability of different sources of global and regional data has resulted in emergence of various data sets, with varying degrees of quality, which can potentially support demand calculation algorithms. At this stage of research, the various data sets have not been systematically compared with respect to their uncertainty and the associated effects on demand simulations. This is a major need for future exploration.

2. Uncertainty in demand calculation algorithms: this includes both irrigative and non-irrigative demands.

a. Irrigative demand: limitations in current algorithms mainly include the uncertainty in describing the crop moisture requirements in time and space and constraining the irrigation to water availability. If the irrigation is limited by the water available at the grid scale, then the quality of simulation is hindered by the ability of the host model to describe water allocation from surface and groundwater resources (see Nazemi and Wheater, 2015). In addition, current bottom-up algorithms do not appropriately consider plant-specific water requirements at the sub-grid scale due to missing soil and crop diversity. This can result in misestimating the irrigation demand. In the best situation, where the same assumption is used for the calculation of the crop evaporation and the irrigation demand, the uncertainty of the irrigative demand is the same as evaporation, but this can still vary greatly across various host models. Considering future simulations, widely used irrigation demand estimates based on FAO guidelines often require several input variables (see, e.g., Farmer et al., 2011 and Hejazi et al., $2013 \mathrm{~b}$, for simplifications), and given the need for downscaling of climate variables for future simulations, these can be outperformed by simpler models (e.g., Vörösmarty et al., 1998; Wisser et al., 2010). At the current stage of research, different methods for calculating irrigative demand have not yet been fully intercompared to identify appropriate algorithms with respect to region, climate and type of crops. This can be considered as an important need for further research. Another avenue for future development is improving the demand simulations us- ing data assimilation and model calibration. These opportunities will be discussed further in Nazemi and Wheater (2015).

b. Non-irrigative demand: the current offline modeling capability is generally temporally coarse, and available downscaling and projection algorithms mainly do not account for seasonal variations in water demand. There are also parametric and structural uncertainties in functional mappings that link water demand to socio-economic and technological proxies due to limitations in available data as well as the diversity and spatiotemporal variability in non-irrigative demands. At this stage, it is not fully understood how these uncertainties propagate into future projections considering additional uncertainty in future climate and socio-economic scenarios. Developing robust downscaling and projection algorithms for estimation of non-irrigative demands therefore is an important need for future development.

3. Uncertainty in host models: host models can add substantial uncertainty to demand simulations, particularly for irrigation. As noted in Sect. 3, the calculation of irrigation demand involves solving the soil water balance at every simulation time step and this is determined by how the relevant natural processes, such as actual evapotranspiration and soil moisture, are parameterized in the host model. Haddeland et al. (2011) showed major differences in the global simulations obtained from six LSMs and five GHMs due to differences in underlying assumptions, process representations, and related parameterizations. It is also shown that considering feedback effects between irrigation and atmosphere can considerably change potential evaporation (e.g., Blyth and Jacobs, 2011; Lu, 2013); therefore offline irrigation demand simulations based on GHMs might be biased as they inherently ignore climate feedbacks. Moreover, GHMs often cannot represent important processes such as the effects of increased carbon concentration on irrigation demand. This limitation may result in major deficiencies in simulating climate change scenarios as $\mathrm{CO}_{2}$ increases can significantly change vegetation dynamics (e.g., Prudhomme et al., 2014), which can further alter the evaporation and runoff regimes (Gerten et al., 2004). From this perspective, it can be concluded that online LSMs are superior to GHMs with respect to simulations under increasing $\mathrm{CO}_{2}$ concentration and future water stress, as they often include many of the required computational components for investigating interactions between climate, carbon, vegetation and water cycles. Efforts are however needed to transfer recent demand calculation algorithms developed in the context of GHMs into LSMs. In addition, although it has been argued that the uncertainties in host models are more 
significant than in climate forcing (e.g., Wada et al., 2013), uncertainties in irrigation algorithms and largescale host models have not been fully disaggregated and distinguished. This requires a "mix and match" of multiple demand algorithms with multiple host models to conduct a systematic intercomparison and sensitivity analysis. This can be considered as an important research direction - see Nazemi and Wheater (2015).

\section{Summary and concluding remarks}

The terrestrial water cycle has been greatly affected in time and space by human activities during the recent past, to the extent that the current geological era has been named the "Anthropocene". Anthropogenic activities, therefore, are required to be represented in models that are used for impact assessments, large-scale hydrological modeling and landatmosphere feedback representations. Current human-water interactions are mainly manifested through water resource management, which can be further broken down into two interacting components, related to water demand as well as water supply and allocation. In this paper we considered the representation of water demand in large-scale models. Water demand was further divided into irrigative and nonirrigative categories. We summarized current demand calculation algorithms based on type of demand, modeling procedure and underlying assumptions. Current applications were overviewed; and limitations in knowledge were identified and discussed. Considering current gaps in representing the anthropogenic demands in large-scale models, three main directions are suggested for future developments. These include (1) systematic intercomparisons between different data sets, demand algorithms and host models and associated uncertainties with respect to different geographic regions as well as various socio-economic and climate conditions; (2) developing improved algorithms for calculating both irrigative and non-irrigative demands in time and space considering data limitations as well as diversity and spatiotemporal variability in human demand; and finally (3) transferring the algorithms developed in the context of GHMs to LSMs for (a) improved irrigation demand calculation under increasing $\mathrm{CO}_{2}$ effects; and (b) further coupled studies with climate models to address various scientific questions with respect to interactions between carbon, irrigation and climate under climate change conditions. Apart from these immediate research needs, efforts are also required to link with socio-economic and energy models to have a full understanding of the dynamic interactions between natural and anthropogenic drivers of human water availability, demand and consumption (Calvin et al., 2013). This seems to be more of a long-term development due to the limitations in current demand algorithms, LSMs as well as socio-economic and energy models.
As a final remark, it must be noted that the effects of water demand on both the terrestrial water cycle and water security cannot be fully studied unless considered in conjunction with water supply and allocation, which determine the extent of human intervention in water cycle. This is particularly important for future predictions, as increasing water scarcity is a major limiting factor for water demand and can substantially increase competition over available water sources. In Nazemi and Wheater (2015), we review how water supply and allocation have been represented at larger scales and been integrated with various water demands and natural land-surface processes at grid and sub-grid scales.

Acknowledgements. The first author would like to thank Amir Aghakouchak for his valuable inputs during the early stages of this survey. The authors gratefully acknowledge the constructive comments from the editor, Jan Polcher, Ingjerd Haddeland, Jason Evans and two anonymous reviewers, which have enabled us to make significant improvements to this paper. Financial support for this study was provided by the Canada Excellence Research Chair in Water Security at the University of Saskatchewan.

Edited by: W. Buytaert

\section{References}

Abdullah, K. B.: Use of water and land for food security and environmental sustainability, Irrig. Drain., 55, 219-222, doi:10.1002/ird.254, 2006.

Adam, J. C. and Lettenmaier, D. P.: Adjustment of global gridded precipitation for systematic bias, J. Geophys. Res., 108, 4257, doi:10.1029/2002JD002499, 2003.

Adam, J. C., Haddeland, I., Su, F., and Lettenmaier, D. P.: Simulation of reservoir influences on annual and seasonal streamflow changes for the Lena, Yenisei and Ob' rivers, J. Geophys. Res.Atmos., 112, D24114, doi:10.1029/2007JD008525, 2007.

Adegoke, J. O., Pielke Sr., R. A., Eastman, J., Mahmood, R., and Hubbard, K. G.: Impact of irrigation on midsummer surface fluxes and temperature under dry synoptic conditions: A regional atmospheric model study of the US High Plains, Mon. Weather Rev., 131, 556-564, 2003.

AghaKouchak, A., Norouzi, H.-R., Madani, K., Mirchi, A., Azarderakhsh, M., Nazemi, A., Nasrollahi, N., Farahmand, A.R., Mehran, A., and Hasanzadeh, E.: Aral Sea syndrome desiccates Lake Urmia: Call for action, Journal of Great Lakes Research, doi:10.1016/j.jglr.2014.12.007, in press, 2014.

Alcamo, J., Döll, P., Kaspar, F., and Siebert, S.: Global change and global scenarios of water use and availability: an application of WaterGAP 1.0, Center for Environmental Systems Research (CESR), University of Kassel, Germany, available at: http://www.usf.uni-kassel.de/usf/archiv/dokumente/projekte/ watergap.teil1.pdf (last access: 6 May 2014), 1997.

Alcamo, J., Döll, P., Henrichs, T., Kaspar, F., Lehner, B., Rösch, T., and Siebert, S.: Development and testing of the WaterGAP 2 global model of water use and availability, Hydrolog. Sci. J., 48, 317-337, 2003. 
Alcamo, J., Flörke, M., and Märker, M.: Future long-term changes in global water resources driven by socio-economic and climatic changes, Hydrolog. Sci. J., 52, 247-275, 2007.

Allen, R. G., Pereira, L. S., Raes, D., and Smith, M.: Crop evapotranspiration-Guidelines for computing crop water requirements-FAO Irrigation and drainage paper 56, FAO, Rome, http://www.engr.scu.edu/ emaurer/classes/ceng140_ watres/handouts/FAO_56_Evapotranspiration.pdf (last access: 6 May 2014), 1998.

Antonellini, M., Mollema, P., Giambastiani, B., Bishop, K., Caruso, L., Minchio, A., Pellegrini, L., Sabia, M., Ulazzi, E., and Gabbianelli, G.: Salt water intrusion in the coastal aquifer of the southern Po Plain, Italy, Hydrogeol. J., 16, 1541-1556, 2008.

Arnell, N. W.: Climate change and global water resources, Global Environ. Change, 9, 31-49, 1999.

Arnell, N. W.: Climate change and global water resources: SRES emissions and socio-economic scenarios, Global Environ. Change, 14, 31-52, 2004.

Arthington, A. H., Bunn, S. E., Poff, N. L., and Naiman, R. J.: The challenge of providing environmental flow rules to sustain river ecosystems, Ecol. Appl., 16, 1311-1318, 2006.

Barella-Ortiz, A., Polcher, J., Tuzet, A., and Laval, K.: Potential evaporation estimation through an unstressed surface-energy balance and its sensitivity to climate change, Hydrol. Earth Syst. Sci., 17, 4625-4639, doi:10.5194/hess-17-4625-2013, 2013.

Barnston, A. G. and Schickedanz, P. T.: The effect of irrigation on warm season precipitation in the southern Great Plains, J. Clim. Appl. Meteorol., 23, 865-888, 1984.

Beddington, J.: Catalysing sustainable water security: role of science, innovation and partnerships, Philos. T. Roy. Soc. A, 371, 414, doi:10.1098/rsta.2012.0414, 2013.

Blanc, E., Strzepek, K., Schlosser, A., Jacoby, H. D., Gueneau, A., Fant, C., Rausch, S., and Reilly, J.: Analysis of U.S. water resources under climate change, MIT Joint Program on the Science and Policy of Global Change, Report No. 239, http://globalchange.mit.edu/files/document/ MITJPSPGC_Rpt239.pdf (last access: 6 May 2014), 2013.

Blyth, E. and Jacobs, C.: Including climate feedbacks in regional water resource assessments, WATCH Water and global change, Report No. 38, http://www.eu-watch.org/publications/ technical-reports (last access: 6 May 2014), 2011.

Bondeau, A., Smith, P. C., Zaehle, S., Schaphoff, S., Lucht, W., Cramer, W., Gerten, D., Lotze-Campen, H., Müller, C., Reichstein, M., and Smith, B.: Modelling the role of agriculture for the 20th century global terrestrial carbon balance, Global Change Biol., 13, 679-706, doi:10.1111/j.13652486.2006.01305.x, 2007.

Bormann, H., Holländer, H. M., Blume, T., Buytaert, W., Chirico, G. B., Exbrayat, J.-F., Gustafsson, D., Hölzel, H., Kraft, P., Krauße, T., Nazemi, A., Stamm, C., Stoll, S., Blöschl, G., and Flühler, H.: Comparative discharge prediction from a small artificial catchment without model calibration: Representation of initial hydrological catchment development, Bodenkultur, 62, 2329, 2011.

Boucher, O., Myhre, G., and Myhre, A.: Direct human influence of irrigation on atmospheric water vapour and climate, Clim. Dynam., 22), 597-603, 2004.

Bowman, D. M. J. S., Balch, J. K., Artaxo, P., Bond, W. J., Carlson, J. M., Cochrane, M. A., D’Antonio, C. M., DeFries, R. S., Doyle,
J. C., Harrison, S. P., Johnston, F. H., Keeley, J. E., Krawchuk, M. A., Kull1, C. A., Marston, J. B., Moritz, M. A., Prentice, I. C., Roos, C. I., Scott, A. C., Swetnam, T. W., van der Werf, G. R., and Pyne, S. J.: Fire in the Earth system, Science, 324, 481-484, 2009.

Brovkin, V., Claussen, M., Driesschaert, E., Fichefet, T., Kicklighter, D., Loutre, M.-F., Matthews, H. D., Ramankutty, N., Schaeffer, M., and Sokolov, A.: Biogeophysical effects of historical land cover changes simulated by six Earth system models of intermediate complexity, Clim. Dynam., 26, 587-600, 2006.

Calvin, K., Wise, M., Clarke, L., Edmonds, J., Kyle, P., Luckow, P., and Thomson, A.: Implications of simultaneously mitigating and adapting to climate change: initial experiments using GCAM, Climatic Change, 117, 545-560, 2013.

Cayan, D. R., Das, T., Pierce, D. W., Barnett, T. P., Tyree, M., and Gershunov, A.: Future dryness in the southwest US and the hydrology of the early 21 st century drought, P. Natl. Acad. Sci., 107, 21271-21276, 2010.

Chaturvedi, V., Hejazi, M., Edmonds, J., Clarke, L., Kyle, P., Davies, E., and Wise, M.: Climate mitigation policy implications for global irrigation water demand, Mitig. Adapt. Strat. Global Change, 18, 1-19, 2013a.

Chaturvedi, V., Hejazi, M., Edmonds, J., Clarke, L., Kyle, P., Davies, E., Wise, M., and Calvin, K. V.: Climate Policy Implications for Agricultural 5 Water Demand, Pacific Northwest National Laboratory, Richland, WA, available at: http://www.globalchange.umd.edu/wp-content/uploads/ projects/PNNL-22356.pdf (last access: 6 May 2014), 2013b.

Chen, F. and Dudhia, J.: Coupling an advanced land surfacehydrology model with the Penn State-NCAR MM5 modeling system Part I: Model implementation and sensitivity, Mon. Weather Rev., 129, 569-585, 2001a.

Chen, F. and Dudhia, J.: Coupling an advanced land surfacehydrology model with the Penn State-NCAR MM5 modeling system Part II: Preliminary model validation, Mon. Weather Rev., 129, 587-604, 2001b.

Chenoweth, J., Hadjikakou, M., and Zoumides, C.: Quantifying the human impact on water resources: a critical review of the water footprint concept, Hydrol. Earth Syst. Sci., 18, 2325-2342, doi:10.5194/hess-18-2325-2014, 2014.

CIA: CIA World Factbook [CD-ROM], Washington, D.C., https: //www.cia.gov/library/publications/the-world-factbook (last access: 6 May 2014), 2001.

CIAT: Gridded Population of the World, Version 3 (GPWv3): Population Density Grid, NASA Socioeconomic Data and Applications Center (SEDAC), http://sedac.ciesin.columbia.edu/data/ set/gpw-v3-population-density (last access: 6 May 2014), 2005.

Claussen, M.: Earth system models, in: Understanding the Earth System: Compartments, Processes and Interactions, edited by: Ehlers, E., and Krafft, T., Springer-Verlag, Heidelberg, 145-162, 2001.

Cole, M. A.: Economic growth and water use, Appl. Econ. Lett., 11, 1-4, 2004.

Collins, W. D., Rasch, P. J., Boville, B. A., Hack, J. J., McCaa, J. R., Williamson, D. L., Briegleb, B., Bitz, C., Lin, S.-J., Zhang, M., and Dai, Y.: Description of the NCAR community atmosphere model (CAM 3.0), NCAR Tech. Note NCAR/TN-464+STR, 226, available at: http://hanson.geog.udel.edu/hanson/hanson/ 
CLD_GCMExperimentS11_files/description.pdf (last access: 6 May 2014), 2004.

Collins, W. D., Rasch, P. J., Boville, B. A., Hack, J. J., McCaa, J. R., Williamson, D. L., Briegleb, B., Bitz, C., Lin, S.-J., and Zhang, M.: The formulation and atmospheric simulation of the Community Atmosphere Model version 3 (CAM3), J. Climate, 19, 2144-2161, 2006.

Compton, E. and Best, M.: Impact of spatial and temporal resolution on modelled terrestrial hydrological cyce components, WATCH Water and global change. Report No. 44, http://www.eu-watch. org/publications/technical-reports (last access: 6 May 2014), 2011.

Cosgrove, B. A., Lohmann, D., Mitchell, K. E., Houser, P. R., Wood, E. F., Schaake J. C., Robock, A., Marshall, C., Sheffield, J., Duan, Q., Luo, L., Wayne Higgins, R., Pinker R. T., Dan Tarpley, J., and Meng, J.: Real-time and retrospective forcing in the North American Land Data Assimilation System (NLDAS) project, J. Geophys. Res., 108, 8842, doi:10.1029/2002JD003118, 2003.

Crutzen, P. J.: The "anthropocene", in: Earth System Science in the Anthropocene, edited by: Ehlers, E., Krafft, T., and Moss, C., Springer, Berlin, Heidelberg, 13-18, 2006.

Crutzen, P. J. and Steffen, W.: How long have we been in the Anthropocene era?, Climatic Change, 61, 251-257, 2003.

Dadson, S., Acreman, M., and Harding, R.: Water security, global change and land-atmosphere feedbacks, Philos. T. Roy. Soc. A, 371, 2002, doi:10.1098/rsta.2012.0412, 2013.

Davies, E. G., Kyle, P., and Edmonds, J. A.: An integrated assessment of global and regional water demands for electricity generation to 2095, Adv. Water Resour., 52, 296-313, 2013.

DeAngelis, A., Dominguez, F., Fan, Y., Robock, A., Kustu, M. D., and Robinson, D.: Evidence of enhanced precipitation due to irrigation over the Great Plains of the United States, J. Geophys. Res., 115, D15115, doi:10.1029/2010JD013892, 2010.

Deardorff, J. W.: Efficient prediction of ground surface temperature and moisture, with inclusion of a layer of vegetation, J. Geophys. Res.-Oceans, 83, 1889-1903, 1978.

Dee, D. P., Uppala, S. M., Simmons, A. J., Berrisford, P., Poli, P., Kobayashi, S., Andrae, U., Balmaseda, M. A., Balsamo, G., Bauer, P., Bechtold, P., Beljaars, A. C. M., van de Berg, L., Bidlot, J., Bormann, N., Delsol, C., Dragani, R., Fuentes, M., Geer, A. J., Haimberger, L., Healy, S. B., Hersbach, H., Hólm, E. V., Isaksen, L., Kållberg, P., Köhler, M., Matricardi, M., McNally, A. P., Monge-Sanz, B. M., Morcrette, J.-J., Park, B.-K., Peubey, C., de Rosnay, P., Tavolato, C., Thépaut, J.-N., and Vitart, F.: The ERA-interim reanalysis: configuration and performance of the data assimilation system, Q. J. Roy. Meteorol. Soc., 137, 553597, doi:10.1002/qj.828, 2011.

de Rosnay, P., Polcher, J., Laval, K., and Sabre, M.: Integrated parameterization of irrigation in the land surface model ORCHIDEE: Validation over Indian Peninsula, Geophys. Res. Lett., 30, 1986, doi:10.1029/2003GL018024, 2003.

Destouni, G., Asokan, S. M., and Jarsjö, J.: Inland hydro-climatic interaction: Effects of human water use on regional climate, Geophys. Res. Lett., 37, L18402, doi:10.1029/2010GL044153, 2010.

Dickinson, R. E.: Land surface processes and climate-surface albedos and energy balance, Adv. Geophys., 25, 305-353, 1983.
Dickinson, R. E.: Modeling evapotranspiration for threedimensional global climate models, Geophys. Monogr. Ser., 29, 58-72, 1984.

Döll, P.: Vulnerability to the impact of climate change on renewable groundwater resources: a global-scale assessment, Environ. Res. Lett., 4, 035006, doi:10.1088/1748-9326/4/3/035006, 2009.

Döll, P. and Siebert, S.: A digital global map of irrigated areas, ICID J., 49, 55-66, 2000.

Döll, P. and Siebert, S.: Global modeling of irrigation water requirements, Water Resour. Res., 38, 8-1-8-10, doi:10.1029/2001WR000355, 2002.

Döll, P., Fiedler, K., and Zhang, J.: Global-scale analysis of river flow alterations due to water withdrawals and reservoirs, Hydrol. Earth Syst. Sci., 13, 2413-2432, doi:10.5194/hess-13-24132009, 2009.

Döll, P., Müller Schmied, H., Schuh, C., Portmann, F. T., and Eicker, A.: Global-scale assessment of groundwater depletion and related groundwater abstractions: Combining hydrological modeling with information from well observations and GRACE satellites. Water Resour. Res., 50, 5698-5720, doi:10.1002/2014WR015595, 2014.

Douglas, E. M., Beltrán-Przekurat, A., Niyogi, D., Pielke Sr., R. A., and Vörösmarty, C. J.: The impact of agricultural intensification and irrigation on land-atmosphere interactions and Indian monsoon precipitation - A mesoscale modeling perspective, Global Planet. Change, 67, 117-128, 2009.

Ducoudré, N. I., Laval, K., and Perrier, A.: SECHIBA, a new set of parameterizations of the hydrologic exchanges at the landatmosphere interface within the LMD atmospheric general circulation model, J. Climate, 6, 248-273, 1993.

Ek, M. B., Mitchell, K. E., Lin, Y., Rogers, E., Grunmann, P., Koren, V., Gayno, G., and Tarpley, J. D.: Implementation of Noah land surface model advances in the National Centers for Environmental Prediction operational mesoscale Eta model, J. Geophys. Res., 108, 8851, doi:10.1029/2002JD003296, 2003.

Eltahir, E. A.: A soil moisture-rainfall feedback mechanism: 1. Theory and observations, Water Resour. Res., 34, 765-776, 1998.

Entekhabi, D. and Eagleson, P. S.: Land surface hydrology parameterization for atmospheric general circulation models including subgrid scale spatial variability, J. Climate, 2, 816-831, 1989.

Evans, J. P. and Zaitchik, B. F.: Modeling the large-scale water balance impact of different irrigation systems, Water Resour. Res., 44, W08448, doi:10.1029/2007WR006671, 2008.

Falkenmark, M.: Growing water scarcity in agriculture: future challenge to global water security, Philos. T. Roy. Soc. A, 371, 2002, doi:10.1098/rsta.2012.0410, 2013.

Farmer, W., Strzepek, K., Schlosser, C. A., Droogers, P., and Gao, X.: A Method for Calculating Reference Evapotranspiration on Daily Time Scales, MIT Joint Program on the Science and Policy of Global Change, Report number 195, http://18.7.29.232/ handle/1721.1/61773 (last access: 6 May 2014), 2011.

Fischer, G., Tubiello, F. N., Van Velthuizen, H., and Wiberg, D. A.: Climate change impacts on irrigation water requirements: effects of mitigation, 1990-2080, Technol. Forecast. Social Change, 74, 1083-1107, 2007.

Flörke, M. and Alcamo, J.: European outlook on water use, Final Report, EEA/RNC/03/007, Center for Environmental Systems Research, University of Kassel, http://www.improve.novozymes. 
com/Documents/European_OutlookonWaterUse.pdf, (last access: 6 May 2014), 2004.

Flörke, M., Kynast, E., Bärlund, I., Eisner, S., Wimmer, F., and Alcamo, J.: Domestic and industrial water uses of the past 60 years as a mirror of socio-economic development: A global simulation study, Global Environ. Change, 23, 144-156, 2013.

Förster, H. and Lilliestam, J.: Modeling thermoelectric power generation in view of climate change, Reg. Environ. Change, 10, 327-338, 2010.

Friedl, M. A., McIver, D. K., Hodges, J. C., Zhanga, X. Y., Muchoneyb, D., Strahlera, A. H., Woodcocka, C. E., Gopala, S., Schneidera, A., Coopera, A., Baccinia, A., Gaoa, F., and Schaafa, C.: Global land cover mapping from MODIS: algorithms and early results, Remote Sens. Environ., 83, 287-302, 2002.

Gao, H., Birkett, C., and Lettenmaier, D. P.: Global monitoring of large reservoir storage from satellite remote sensing, Water Resour. Res., 48, W09504, doi:10.1029/2012WR012063, 2012.

Gaybullaev, B., Chen, S. C., and Kuo, Y. M.: Large-scale desiccation of the Aral Sea due to over exploitation after 1960, J. Mount. Sci., 9, 538-546, 2012.

Gerten, D.: A vital link: water and vegetation in the Anthropocene, Hydrol. Earth Syst. Sci., 17, 3841-3852, doi:10.5194/hess-173841-2013, 2013.

Gerten, D. and Rost, S.: Climate change impacts on agricultural water stress and impact mitigation potential, World Bank, Washington, D.C., USA, http://siteresources.worldbank. org/INTWDR2010/Resources/5287678-1255547194560/

WDR2010_BGNoteGerten.pdf (last access: 3 November 2014), 2010.

Gerten, D., Schaphoff, S., Haberlandt, U., Lucht, W., and Sitch, S.: Terrestrial vegetation and water balance - hydrological evaluation of a dynamic global vegetation model, J. Hydrol., 286, 249270, 2004.

Gerten, D., Hagemann, S., Biemans, H., Saeed, F., and Konzmann, M.: Climate Change and Irrigation: Global Impacts and Regional Feedbacks, WATCH Technical Report Number 47, http: //www.eu-watch.org/publications/technical-reports (last access: 6 May 2014), 2011.

GEWEX: GEWEX plans for 2013 and beyond - GEWEX science questions (version 1), GEWEX document series No. 20122, http://www.gewex.org/pdfs/GEWEXScience_Questionsfinal. pdf, (last access: 6 May 2014), 2012.

Giordano, M.: Global groundwater? Issues and solutions, Annu. Rev. Environ. Resour., 34, 153-178, 2009.

Gleeson, T., Wada Y., Bierkens, M. F., and van Beek, L. P.: Water balance of global aquifers revealed by groundwater footprint, Nature, 488, 197-200, 2012.

Gleick, P. H.: Basic water requirements for human activities: Meeting basic needs, Water Int., 21, 83-92, 1996.

Gleick, P. H.: Water use, Annual Rev. Environ. Resour., 28, 275314, 2003.

Gleick, P. H., Cooley, H., Famiglietti, J. S., Lettenmaier, D. P., Oki, T., Vörösmarty, C. J., and Wood, E. F.: Improving Understanding of the Global Hydrologic Cycle, in: Climate Science for Serving Society, edited by: Asrar, G. R. and Hurrell, J. W., Springer Netherlands, 151-184, 2013.

Gober, P. and Wheater, H. S.: Socio-hydrology and the sciencepolicy interface: a case study of the Saskatchewan River basin,
Hydrol. Earth Syst. Sci., 18, 1413-1422, doi:10.5194/hess-181413-2014, 2014.

Gosling, S. N., Taylor, R. G., Arnell, N. W., and Todd, M. C.: A comparative analysis of projected impacts of climate change on river runoff from global and catchment-scale hydrological models, Hydrol. Earth Syst. Sci., 15, 279-294, doi:10.5194/hess-15279-2011, 2011.

Grey, D., Garrick, D., Blackmore, D., Kelman, J., Muller, M., and Sadoff, C.: Water security in one blue planet: twenty-first century policy challenges for science, Philos. T. Roy. Soc. A, 371, 2002, doi:10.1098/rsta.2012.0406, 2013.

Gueneau, A., Schlosser, C. A., Strzepek, K. M., Gao, X., and Monier, E.: CLM-AG: An Agriculture Module for the Community Land Model version 3.5, MIT Joint Program on the Science and Policy of Global Change, http://dspace.mit.edu/handle/1721. 1/73007 (last access: 6 May 2014), 2012.

Guimberteau, M., Laval, K., Perrier, A., and Polcher, J.: Global effect of irrigation and its impact on the onset of the Indian summer monsoon, Clim. Dynam., 39, 1329-1348, doi:10.1007/s00382011-1252-5, 2012.

Haddeland, I., Lettenmaier, D. P., and Skaugen T.: Effects of irrigation on the water and energy balances of the Colorado and Mekong river basins, J. Hydrol., 324, 210-223, 2006.

Haddeland, I., Skaugen, T., and Lettenmaier, D. P.: Hydrologic effects of land and water management in North America and Asia: 1700-1992, Hydrol. Earth Syst. Sci., 11, 1035-1045, doi:10.5194/hess-11-1035-2007, 2007.

Haddeland, I., Clark, D. B., Franssen, W., Ludwig, F., Voß, F., Arnell, N. W., Bertrand, N., Best, M., Folwell, S., Gerten, D., Gomes, S., Gosling, S. N., Hagemann, S., Hanasaki, N., Harding, R., Heinke, J., Kabat, P., Koirala, S., Oki, T., Polcher, J., Stacke, T., Viterbo, P., Weedon, G. P., and Yeh, P.: Multimodel estimate of the global terrestrial water balance: setup and first results, J. Hydrometeorol., 12, 869-884, doi:10.1175/2011JHM1324.1, 2011.

Haddeland, I., Biemans, H., Eisner, S., Flörke, M., Hanasaki, N., Konzmann, M., Ludwig, F., Masaki, Y., Schewe, J., Stacke, T., Tessler, Z. D., Wada, Y., and Wisser, D.: Global water resources affected by human interventions and climate change, P. Natl. Acad. Sci., 111, 3251-3256, doi:10.1073/pnas.1222475110, 2014.

Hagemann, S. and Dümenil, L.: A parameterization of the lateral waterflow for the global scale, Clim. Dynam., 14, 17-31, doi:10.1007/s003820050205, 1997.

Hanasaki, N., Kanae, S., and Oki, T.: A reservoir operation scheme for global river routing models, J. Hydrol., 327, 22-41, 2006.

Hanasaki, N., Kanae, S., Oki, T., Masuda, K., Motoya, K., Shirakawa, N., Shen, Y., and Tanaka, K.: An integrated model for the assessment of global water resources - Part 1: Model description and input meteorological forcing, Hydrol. Earth Syst. Sci., 12, 1007-1025, doi:10.5194/hess-12-1007-2008, 2008a.

Hanasaki, N., Kanae, S., Oki, T., Masuda, K., Motoya, K., Shirakawa, N., Shen, Y., and Tanaka, K.: An integrated model for the assessment of global water resources - Part 2: Applications and assessments, Hydrol. Earth Syst. Sci., 12, 1027-1037, doi:10.5194/hess-12-1027-2008, 2008b.

Hanasaki, N., Inuzuka, T., Kanae, S., and Oki, T.: An estimation of global virtual water flow and sources of water withdrawal for 
major crops and livestock products using a global hydrological model, J. Hydrol., 384, 232-244, 2010.

Hanasaki, N., Fujimori, S., Yamamoto, T., Yoshikawa, S., Masaki, Y., Hijioka, Y., Kainuma, M., Kanamori, Y., Masui, T., Takahashi, K., and Kanae, S.: A global water scarcity assessment under Shared Socio-economic Pathways - Part 1: Water use, Hydrol. Earth Syst. Sci., 17, 2375-2391, doi:10.5194/hess-17-23752013, 2013a.

Hanasaki, N., Fujimori, S., Yamamoto, T., Yoshikawa, S., Masaki, Y., Hijioka, Y., Kainuma, M., Kanamori, Y., Masui, T., Takahashi, K., and Kanae, S.: A global water scarcity assessment under Shared Socio-economic Pathways - Part 2: Water availability and scarcity, Hydrol. Earth Syst. Sci., 17, 2393-2413, doi:10.5194/hess-17-2393-2013, 2013b.

Harding, K. J. and Snyder, P. K.: Modeling the Atmospheric Response to Irrigation in the Great Plains, Part I: General Impacts on Precipitation and the Energy Budget, J. Hydrometeorol., 13, 1667-1686, 2012a.

Harding, K. J. and Snyder, P. K.: Modeling the atmospheric response to irrigation in the Great Plains, Part II: The precipitation of irrigated water and changes in precipitation recycling, $\mathrm{J}$. Hydrometeorol., 13, 1687-1703, 2012b.

Hejazi, M. I., Edmonds, J., Chaturvedi, V., Davies, E., and Eom, J.: Scenarios of global municipal water-use demand projections over the 21st century, Hydrolog. Sci. J., 58, 519-538, 2013a.

Hejazi, M. I., Edmonds, J., Clarke, L., Kyle, P., Davies, E., Chaturvedi, V., Wise, M., Patel, P., Eom, J., and Calvin, K.: Integrated assessment of global water scarcity over the 21 st century - Part 1: Global water supply and demand under extreme radiative forcing, Hydrol. Earth Syst. Sci. Discuss., 10, 3327-3381, doi:10.5194/hessd-10-3327-2013, 2013b.

Hejazi, M. I., Edmonds, J., Clarke, L., Kyle, P., Davies, E., Chaturvedi, V., Eom, J., Wise, M., Patel, P., and Calvin, K.: Integrated assessment of global water scarcity over the 21st century - Part 2: Climate change mitigation policies, Hydrol. Earth Syst. Sci. Discuss., 10, 3383-3425, doi:10.5194/hessd-10-3383-2013, 2013c.

Hejazi M. I., Edmonds, J. A., Clarke, L. A., Kyle, G. P., Davies, E., Chaturvedi, V., Wise, M. A., Patel, P. L., Eom, J., Calvin, K. V., Moss, R. H., and Kim, S. H.: Long-term global water projections using six socioeconomic scenarios in an integrated assessment modeling framework, Technol. Forecast. Soc., 81, 205226, 2013d.

Hobbins, M. T., Dai, A., Roderick, M. L., and Farquhar, G. D.: Revisiting the parameterization of potential evaporation as a driver of long-term water balance trends, Geophys. Res. Lett., 35, L12403, doi:10.1029/2008GL033840, 2008.

Hossain, F., Degu, A. M., Yigzaw, W., Burian, S., Niyogi, D., Shepherd, J. M., and Pielke Sr., R.: Climate Feedback-Based Provisions for Dam Design, Operations, and Water Management in the 21st Century, J. Hydrol. Eng., 17, 837-850, 2012.

Hourdin, F., Musat, I., Bony, S., Braconnot, P., Codron, F., Dufresne, J.-L., Fairhead, L., Filiberti, M.-A., Friedlingstein, P., Grandpeix, J.-Y., Krinner, G., LeVan, P., Li, Z.-X.: The LMDZ4 general circulation model: climate performance and sensitivity to parametrized physics with emphasis on tropical convection, Clim. Dynam., 27, 787-813, doi:10.1007/s00382-006-0158-0, 2006.
Hughes, G., Chinowsky, P., and Strzepek, K.: The costs of adaptation to climate change for water infrastructure in OECD countries, Utilities Policy, 18, 142-153, 2010.

IIASA/FAO: Global Agro-ecological Zones (GAEZ v3.0), IIASA, Laxenburg, Austria and FAO, Rome, Italy, available at: http://webarchive.iiasa.ac.at/Research/LUC/GAEZv3.0/docs/ GAEZModelDocumentation.pdf (last access: 15 July 2014), 2012.

IPCC: The IPCC Special Report on Emissions Scenarios (SRES), IPCC, Geneva, http://www.ipcc.ch/pdf/special-reports/ spm/sres-en.pdf (last access: 6 May 2014), 2000.

Kalnay, E., Kanamitsu, M., Kistler, R., Collins, W., Deaven, D., Gandin, L., Iredell, M., Saha, S., White, G., Woollen, J., Zhu, Y., Leetmaa, A., Reynolds, R., Chelliah, M., Ebisuzaki, W., Higgins, W., Janowiak, J., Mo, K. C., Ropelewski, C., Wang, J., Jenne, R., and Joseph, D.: The NCEP/NCAR 40-year reanalysis project, B. Am. Meteorol. Soc., 77, 437-471, 1996.

Kanamitsu, M., Ebisuzaki, W., Woollen, J., Yang, S.-K., Hnilo, J. J., Fiorino, M., and Potter, G. L.: NCEP-DOE AMIP-II Reanalysis (R-2), B. Am. Meteorol. Soc., 83, 1631-1644, 2002.

Karl, T. R. and Trenberth K. E.: Modern global climate change, Science, 302, 1719-1723, 2003.

Kim, H., Yeh, P. J.-F., Oki, T., and Kanae, S.: Role of rivers in the seasonal variations of terrestrial water storage over global basins, Geophys. Res. Lett., 36, L17402, doi:10.1029/2009GL039006, 2009.

Konar, M., Hussein, Z., Hanasaki, N., Mauzerall, D. L., and Rodriguez-Iturbe, I.: Virtual water trade flows and savings under climate change, Hydrol. Earth Syst. Sci., 17, 3219-3234, doi:10.5194/hess-17-3219-2013, 2013.

Konzmann, M., Gerten, D., and Heinke, J.: Climate impacts on global irrigation requirements under $19 \mathrm{GCMs}$, simulated with a vegetation and hydrology model, Hydrolog. Sci. J., 58, 88-105, 2013.

Koster, R. D., Dirmeyer, P. A., Guo, Z., Bonan, G., Chan, E., Cox, P., Gordon, C. T., Kanae, S., Kowalczyk, E., Lawrence, D., Liu, P., Lu, C.-H., Malyshev, S., McAvaney, B., Mitchell, K., Mocko, D., Oki, T., Oleson, K., Pitman, A., Sud, Y. C., Taylor, C. M., Verseghy, D., Vasic, R., Xue, Y., and Yamada, T.: Regions of strong coupling between soil moisture and precipitation, Science, 305, 1138-1140, 2004.

Kriegler, E., O’Neill, B. C., Hallegatte, S., Kram, T., Lempert, R. J., Moss, R. H., and Wilbanks, T.: The need for and use of socio-economic scenarios for climate change analysis: a new approach based on shared socio-economic pathways, Global Environ. Change, 22, 807-822, 2012.

Krysanova, V., Müller-Wohlfeil, D. I., and Becker, A.: Development and test of a spatially distributed hydrological/water quality model for mesoscale watersheds, Ecol. Model., 106, 261-289, 1998.

Kump, L. R., Kasting, J. F., and Crane, R. G.: The earth system, Prentice Hall, San Francisco, 2010.

Kyle, P., Davies, E. G., Dooley, J. J., Smith, S. J., Clarke, L. E., Edmonds, J. A., and Hejazi, M.: Influence of climate change mitigation technology on global demands of water for electricity generation, Int. J. Greenh. Gas Con., 13, 112-123, 2013.

Lai, X., Jiang, J., Yang, G., and Lu, X. X.: Should the Three Gorges Dam be blamed for the extremely low water levels in the 
middle-lower Yangtze River?, Hydrol. Process., 28, 150-160, doi:10.1002/hyp.10077, 2014.

Lawrence, D. M., Oleson, K. W., Flanner, M. G., Thornton, P. E., Swenson, S. C., Lawrence, P. J., Zeng, X., Yang, Z.-L., Levis, S., Sakaguchi, K., Bonan, G. B., and Slater, A. G.: Parameterization improvements and functional and structural advances in Version 4 of the Community Land Model, J. Adv. Model. Earth Syst., 3, M03001, doi:10.1029/2011MS00045, 2011.

Lawrence, D., Maxwell, R., Swenson, S., Lopez, S., and Famiglietti, J.: Challenges of Representing and Predicting Multi-Scale Human-Water Cycle Interactions in Terrestrial Systems, http://climatemodeling.science.energy.gov/sites/ default/files/Topic_3_final.pdf (last access: 6 May 2014), 2012.

Leng, G., Huang, M., Tang, Q., Sacks, W. J., Lei, H., and Leung, L. R.: Modeling the effects of irrigation on land surface fluxes and states over the conterminous United States: Sensitivity to input data and model parameters, J. Geophys. Res.-Atmos., 118, 97899803, doi:10.1002/jgrd.50792, 2013.

Lenton, T. M.: Land and ocean carbon cycle feedback effects on global warming in a simple Earth system model, Tellus B, 52, 1159-1188, 2000.

Levis, S. and Sacks W.: Technical descriptions of the interactive crop management (CLM4CNcrop) and interactive irrigation models in version 4 of the Community Land Model, http://www.cesm.ucar.edu/models/cesm1.1/ clm/CLMcropANDirrigTechDescriptions.pdf (last access: 6 May 2014), 2011.

Levis, S., Bonan, G. B., Kluzek, E., Thornton, P. E., Jones, A., Sacks, W. J., and Kucharik, C. J.: Interactive Crop Management in the Community Earth System Model (CESM1): Seasonal Influences on Land-Atmosphere Fluxes, J. Climate, 25, 48394859, 2012.

Li, H., Wigmosta, M. S., Wu, H., Huang, M., Ke, Y., Coleman, A. M., and Leung, L. R.: A physically based runoff routing model for landsurface and earth system models, J. Hydrometeorol., 14, 808-828, 2013.

Liang, X., Lettenmaier, D. P., Wood, E. F., and Burges, S. J.: A simple hydrologically based model of land surface water and energy fluxes for general circulation models, J. Geophys. Res.-Atmos., 99, 14415-14428, 1994.

Lissner, T. K., Sullivan, C. A., Reusser, D. E., and Kropp, J. P.: Water stress and livelihoods: A review of data and knowledge on water needs, use and availability, in: 4th EGU Leonardo Conference: Hydrology and Society - Connections between Hydrology and Population dynamics, Policymaking and Power generation, 14-16 November, Torino, Italy, 2012.

Liu, J., Zhang, Z., Xu, X., Kuang, W., Zhou, W., Zhang, S., Li, R., Yan, C., Yu, D., Wu, S., and Jiang N.: Spatial patterns and driving forces of land use change in China during the early 21 st century, J. Geogr. Sci., 20, 483-494, 2010.

Livneh, B., Restrepo, P. J., and Lettenmaier, D. P.: Development of a Unified Land Model for prediction of surface hydrology and land-atmosphere interactions, J. Hydrometeorol., 12, 12991320, 2011.

Lo, M.-H. and Famiglietti, J. S.: Irrigation in California's Central Valley strengthens the southwestern U.S. water cycle, Geophys. Res. Lett., 40, 301-306, doi:10.1002/grl.50108, 2013.
Lobell, D. B., Bala, G., and Duffy, P. B.: Biogeophysical impacts of cropland management changes on climate, Geophys. Res. Lett., 33, L06708, doi:10.1029/2005GL025492, 2006.

Lorenz, C. and Kunstmann, H.: The Hydrological Cycle in Three State-of-the-Art Reanalyses: Intercomparison and Performance Analysis, J. Hydrometeorol., 13, 1397-1420, 2012.

Lu, Y.: Development and application of WRF3.3-CLM4crop to study of agriculture-climate interaction, $\mathrm{PhD}$ Thesis, University of California, Merced, http://escholarship.org/uc/item/12b6p87z (last access: 6 May 2014), 2013.

Lucas-Picher, P., Christensen, J. H., Saeed, F., Kumar, P., Asharaf, S., Ahrens, B., Wiltshire, A. J., Jacob, D., and Hagemann, S.: Can regional climate models represent the Indian monsoon?, J. Hydrometeorol., 12, 849-868, 2011.

Macknick, J., Newmark, R., Heath, G., and Hallett, K. C.: A review of operational water consumption and withdrawal factors for electricity generating technologies, Technical Report NREL/TP-6A20-5090, http://www.cwatershedalliance.com/pdf/ SolarDoc01.pdf (last access: 6 May 2014), 2011.

Manabe, S.: Climate and the ocean circulation part I. The atmospheric circulation and the hydrology of the earth's surface, Mon. Weather Rev., 97, 739-774, 1969.

Maurer, E. P., Wood, A. W., Adam, J. C., Lettenmaier, D. P., and Nijssen, B.: A long-term hydrologically based dataset of land surface fluxes and states for the conterminous United States, J. Climate, 15, 3237-3251, 2002.

McKenney, M. S. and Rosenberg, N. J.: Sensitivity of some potential evapotranspiration estimation methods to climate change, Agr. Forest Meteorol., 64, 81-110, 1993.

McNeill, J. R.: Something New Under the Sun: An Environmental History of the Twentieth-Century World, WW Norton \& Company, New York, 2000.

Mehta, V. K., Haden V. R., Joyce, B. A., Purkey, D. R., and Jackson, L. E.: Irrigation demand and supply, given projections of climate and land-use change in Yolo County, California, Agr. Water Manage., 117, 70-82, 2013.

Meinshausen, M., Smith, S. J., Calvin, K., Daniel, J. S., Kainuma, M. L. T., Lamarque, J.-F., Matsumoto, K., Montzka, S. A., Raper, S. C. B., Riahi, K., Thomson, A., Velders, G. J. M., and van Vuuren, D. P. P.: The RCP greenhouse gas concentrations and their extensions from 1765 to 2300, Climatic Change, 109, 213-241, 2011.

Meybeck, M.: Global analysis of river systems: from Earth system controls to Anthropocene syndromes, Philos. T. Roy. Soc. Lond. B, 358, 1935-1955, 2003.

Milano, M., Ruelland, D., Fernandez, S., Dezetter, A., Fabre, J., Servat, E., Fritsch, J.-M., Ardoin-Bardin, S., and Thivet, G.: Current state of Mediterranean water resources and future trends under climatic and anthropogenic changes, Hydrolog. Sci. J., 58, 498518, 2013.

Miller, J. R., Russell, G. L., and Caliri, G.: Continentalscale river flow in climate models, J. Climate, 7, 914-928, doi:10.1175/1520-0442(1994)007<0914:CSRFIC>2.0.CO;2, 1994.

Milly, P. C. D.: Potential evaporation and soil moisture in general circulation models, J. Climate, 5, 209-226, 1992.

Mitchell, T. D. and Jones, P. D.: An improved method of constructing a database of monthly climate observations and as- 
sociated high-resolution grids, Int. J. Climatol., 25, 693-712, doi:10.1002/joc.1181, 2005.

Moore, N. and Rojstaczer, S.: Irrigation-induced rainfall and the Great Plains, J. Appl. Meteorol., 40, 1297-1309, 2001.

Moss, R. H., Edmonds, J. A., Hibbard, K. A., Manning, M. R., Rose, S. K., van Vuuren, D. P., Carter, T. R., Emori, S., Kainuma, M., Kram, T., Meehl, G. A., Mitchell, J. F. B., Nakicenovic, N., Riahi, K., Smith, S. J., Stouffer, R. J., Thomson, A. M., Weyant, J. P., and Wilbanks, T. J.: The next generation of scenarios for climate change research and assessment, Nature, 463, 747-756, 2010.

Music, B. and Caya, D.: Evaluation of the hydrological cycle over the Mississippi River basin as simulated by the Canadian Regional Climate Model (CRCM), J. Hydrometeorol., 8, 969-988, 2007.

Nakayama, T.: Simulation of the effect of irrigation on the hydrologic cycle in the highly cultivated Yellow River Basin, Agr. Forest Meteorol., 151, 314-327, 2011.

Nakayama, T. and Shankman D.: Evaluation of uneven water resource and relation between anthropogenic water withdrawal and ecosystem degradation in Changiiang and Yellow River basins, Hydrol. Process., 27, 3350-3362, doi:10.1002/hyp.9835, 2013.

Nassopoulos, H., Dumas, P., and Hallegatte, S.: Climate change, precipitation and water management infrastructures, presented at: Water in Africa: Hydro-Pessimism or Hydro-Optimism, 2-3 October 2008, Porto, Portugal, available at:http://www.slideshare.net/water.in.africa/ hypatia-nassopoulos-ppt-presentation (last access: 15 October 2014), 2008.

Nassopoulos, H., Dumas, P., and Hallegatte, S.: Adaptation to an uncertain climate change: cost benefit analysis and robust decision making for dam dimensioning, Climatic Change, 114, 497508, doi:10.1007/s10584-012-0423-7, 2012.

Nazemi, A. and Wheater, H. S.: Assessing the vulnerability of water supply to changing streamflow conditions, Eos Trans. Am. Geophys. Un., 95, 288, doi:10.1002/2014EOS320007, 2014a.

Nazemi, A. and Wheater, H. S.: How can the uncertainty in the natural inflow regime propagate into the assessment of water resource systems?, Adv. Water Resour., 63, 131-142, doi:10.1016/j.advwatres.2013.11.009, 2014b.

Nazemi, A. and H. S. Wheater: On inclusion of water resource management in Earth System models - Part 2: Representation of water supply and allocation and opportunities for improved modeling, Hydrol. Earth Syst. Sci., 19, 63-90, doi:10.5194/hess-1963-2015, 2015.

Nazemi, A., Akbarzadeh-T, M. R., and Hosseini, S. M.: Fuzzystochastic linear programming in water resources engineering, in: Proceedings of IEEE Annual Meeting of Fuzzy Information, IEEE, 227-232, doi:10.1109/NAFIPS.2002.1018060, 2002.

Nazemi, A., Wheater, H. S., Chun, K. P., and Elshorbagy, A.: A stochastic reconstruction framework for analysis of water resource system vulnerability to climate-induced changes in river flow regime, Water Resour. Res., 49, 291-305, doi:10.1029/2012WR012755, 2013.

New, M., Hulme, M., and Jones, P.: Representing TwentiethCentury Space-Time Climate Variability Part I: Development of a 1961-90 Mean Monthly Terrestrial Climatology, J.f Climate, 12, 829-857, 1999.

New, M., Hulme, M., and Jones, P. D.: Representing twentieth century space-time climate variability, part II Development of 1901-
96 monthly grids of terrestrial surface climate, J. Climate, 13 2217-2238, 2000 .

Ngo-Duc, T., Laval, K., Polcher, J., Lombard, A., and Cazenave, A.: Effects of land water storage on global mean sea level over the past half century, Geophys. Res. Lett., 32, L09704, doi:10.1029/2005GL022719, 2005a.

Ngo-Duc, T., Polcher, J., and Laval, K.: A 53-year forcing data set for land surface models, J. Geophys. Res., 110, D06116, doi:10.1029/2004JD005434, 2005b.

Ngo-Duc, T., Laval, K., Ramillien, G., Polcher, J., and Cazenave, A.: Validation of the land water storage simulated by Organising Carbon and Hydrology in Dynamic Ecosystems (ORCHIDEE) with Gravity Recovery and Climate Experiment (GRACE) data, Water Resour. Res., 43, W04427, doi:10.1029/2006WR004941, 2007.

Nicholson, S. E.: Land surface atmosphere interaction, Prog. Phys. Geogr., 12, 36-65, 1988.

Nilsson, C., Reidy, C. A., Dynesius, M., and Revenga, C.: Fragmentation and flow regulation of the world's large river systems, Science, 308, 405-408, 2005.

Noilhan, J. and Planton, S.: A simple parameterization of land surface processes for meteorological models, Mon. Weather Rev., 117, 536-549, 1989.

Oki, T. and Kanae, S.: Global hydrological cycles and world water resources, Science, 313, 1068-1072, 2006.

Oki, T. and Sud, Y. C.: Design of Total Runoff Integrating Pathways (TRIP) - A global river channel network, Earth Interact., 2, 1-37, 1998.

Oki, T., Blyth, E. M., Berbery, E. H., and Alcaraz-Segura, D.: Land Use and Land Cover Changes and Their Impacts on Hydroclimate, Ecosystems and Society, in: Climate Science for Serving Society, edited by: Asrar, G. R. and Hurrell, J. W., Springer Netherlands, 185-203, 2013.

Oleson, K. W., Dai, Y., Bonan, G. B., Bosilovichm, M., Dickinson, R., Dirmeyer, P., Hoffman, F., Houser, P., Levis, S., Niu, G.-Y., Thornton, P., Vertenstein, M., Yang, Z., and Zeng, X.: Technical description of the community land model (CLM), NCAR Tech. Note NCAR/TN-461+STR, 173 pp., doi:10.5065/D6N877R0, http://www.cesm.ucar.edu/models/ cesm1.0/clm/CLM4_Tech_Note.pdf (last access: 28 December 2014), 2004.

Oleson, K. W., Niu, G. Y., Yang, Z. L., Lawrence, D. M., Thornton, P. E., Lawrence, P. J., Stöckli, R., Dickinson, R. E., Bonan, G. B., Levis, S., Dai, A., and Qian, T.: Improvements to the Community Land Model and their impact on the hydrological cycle, J. Geophys. Res.-Biogeo., 113, G01021, doi:10.1029/2007JG000563, 2008.

Ozdogan, M. and Gutman, G.: A new methodology to map irrigated areas using multi-temporal MODIS and ancillary data: An application example in the continental US, Remote Sens. Environ., 112, 3520-3537, 2008.

Ozdogan, M., Rodell, M., Beaudoing, H. K., and Toll, D. L.: Simulating the Effects of Irrigation over the United States in a Land Surface Model Based on Satellite-Derived Agricultural Data, J. Hydrometeorol., 11, 171-184, 2010.

Pielke, R. A., Cotton, W. R., Walko, R. L., Tremback, C. J., Lyons, W. A., Grasso, L. D., Nicholls, M. E., Moran, M. D., Wesley, D. A., Lee, T. J., and Copeland, J. H.: A comprehensive meteoro- 
logical modeling system - RAMS, Meteorol. Atmos. Phys., 49, 69-91, 1992.

Pietroniro, A., Fortin, V., Kouwen, N., Neal, C., Turcotte, R., Davison, B., Verseghy, D., Soulis, E. D., Caldwell, R., Evora, N., and Pellerin, P.: Development of the MESH modelling system for hydrological ensemble forecasting of the Laurentian Great Lakes at the regional scale, Hydrol. Earth Syst. Sci., 11, 1279-1294, doi:10.5194/hess-11-1279-2007, 2007.

Pitman, A. J.: The evolution of, and revolution in, land surface schemes designed for climate models, Int. J. Climatol., 23, 479$510,2003$.

Pitman, A. J., Henderson-Sellers, A., and Yang, Z. L.: Sensitivity of regional climates to localized precipitation in global models, Nature, 346, 734-737, 1990.

Pitman, A. J., de Noblet-Ducoudré, N., Cruz, F. T., Davin, E. L., Bonan, G. B., Brovkin, V., Claussen, M., Delire, C., Ganzeveld, L., Gayler, V., van den Hurk, B. J. J. M., Lawrence, P. J., van der Molen, M. K., Müller, C., Reick, C. H., Seneviratne, S. I., Strengers, B. J., and Voldoire, A.: Uncertainties in climate responses to past land cover change: first results from the LUCID intercomparison study, Geophys. Res. Lett., 36, L14814, doi:10.1029/2009GL039076, 2009.

Pokhrel, Y., Hanasaki, N., Koirala, S., Cho, J., Yeh, P. J.-F., Kim, H., Kanae, S., and Oki, T.: Incorporating anthropogenic water regulation modules into a land surface model, J. Hydrometeorol., 13, 255-269, 2012.

Polcher, J.: Interactive comment on "On inclusion of water resource management in Earth System models - Part 1: Problem definition and representation of water demand" by A. Nazemi and H. S. Wheater, Hydrol. Earth Syst. Sci. Discuss., 11, C3403C3410, 2014.

Polcher, J., Bertrand, N., Biemans, H., Clark, D. B., Floerke, M., Gedney, N., Gerten, D., Stacke, T., van Vliet, M., and Voss, F.: Improvements in hydrological processes in general hydrological models and land surface models within WATCH, WATCH Technical Report Number 34, available at: http://www.eu-watch.org/ publications/technical-reports (last access: 6 May 2014), 2011.

Poff, N. L., Richter, B. D., Arthington, A. H., Bunn, S. E., Naiman, R. J., Kendy, E., Acreman, M., Apse, C., Bledsoe, B. P., Freeman, M. C., Henriksen, J., Jacobson, R. B., Kennen, J. G., Merritt, D. M., O'Keeffe, J. H., Olden, J. D., Rogers, K., Tharme, R. E., and Warner, A.: The ecological limits of hydrologic alteration (ELOHA): a new framework for developing regional environmental flow standards, Freshwater Biol., 55, 1365-2427, doi:10.1111/j.1365-2427.2009.02204.x, 2009.

Portmann, F. T., Siebert, S., and Döll, P.: MIRCA2000 - Global monthly irrigated and rainfed crop areas around the year 2000: A new high-resolution data set for agricultural and hydrological modeling, Global Biogeochem. Cycl., 24, GB1011, doi:10.1029/2008GB003435, 2010.

Postel, S. L., Daily, G. C., and Ehrlich, P. R.: Human appropriation of renewable fresh water, Science, 271, 785-788, 1996.

Precoda, N.: Requiem for the Aral Sea, Ambio, 20, 109-114, 1991.

Priestley, C. H. B. and Taylor, R. J.: On the assessment of surface heat flux and evaporation using large-scale parameters, Mon. Weather Rev., 100, 81-92, 1972.

Prudhomme, C., Giuntoli, I., Robinson, E. L., Clark, D. B., Arnell, N. W., Dankers, R., Fekete, B. M., Franssen, W., Gerten, D., Gosling, S. N., Hagemann, S., Hannah, D. M., Kim, H., Masaki,
Y., Satoh, Y., Stacke, T., Wada, Y., and Wisser, D.: Hydrological droughts in the 21 st century, hotspots and uncertainties from a global multimodel ensemble experiment, P. Natl. Acad. Sci. USA, 111, 3262-3267, doi:10.1073/pnas.1222473110, 2014.

Qian, Y., Huang, M., Yang, B., and Berg, L. K.: A Modeling Study of Irrigation Effects on Surface Fluxes and Land-Air-Cloud Interactions in the Southern Great Plains, J. Hydrometeorol., 14, 700-721, 2013.

Rausch, S. and Mowers, M.: Distributional and efficiency impacts of clean and renewable energy standards for electricity, Resour. Energy Econ., 36, 556-585, 2013.

Rodell, M., Velicogna, I., and Famiglietti, J. S.: Satellite-based estimates of groundwater depletion in India, Nature, 460, 999-1002, 2009.

Rohling, E. J. and Bryden, H. L.: Man-induced salinity and temperature increases in western Mediterranean deep water, J. Geophys. Res.-Oceans (1978-2012), 97, 11191-11198, 1992.

Rosenzweig, C., Elliott, J., Deryng, D., Ruane, A. C., Müller, C., Arneth, A., Boote, K. J., Folberth, C., Glotter, M., Khabarov, N., Neumann, K., Piontek, F., Pugh, T. A. M., Schmid, E., Stehfest, E., Yang, H., and Jones, J. W.: Assessing agricultural risks of climate change in the 21 st century in a global gridded crop model intercomparison, P. Natl. Acad. Sci. USA, 111, 32683273, doi:10.1073/pnas.1222463110, 2014.

Rost, S., Gerten, D., Bondeau, A., Luncht, W., Rohwer, J., and Schaphoff, S.: Agricultural green and blue water consumption and its influence on the global water system, Water Resour. Res., 44, W09405, doi:10.1029/2007WR006331, 2008.

Rost, S., Gerten, D., Hoff, H., Lucht, W., Falkenmark, M., and Rockström, J.: Global potential to increase crop production through water management in rainfed agriculture, Environ.1 Res. Lett., 4, 044002, doi:10.1088/1748-9326/4/4/044002, 2009.

Rudolf, B., Beck, C., Grieser, J., and Schneider, U.: Global precipitation analysis products of the GPCC, Climate Monitoring - Tornadoklimatologie - Aktuelle Ergebnisse des Klimamonitorings, available at: http://www.juergen-grieser.de/publications/ publications_pdf/GPCC-intro-products-2005.pdf, last access: 16 July 2014, 163-170, 2005.

Sacks, W. J., Cook, B. I., Buenning, N., Levis, S., and Helkowski, J. H.: Effects of global irrigation on the near-surface climate, Clim. Dynam., 33, 159-175, 2009.

Saeed, F., Hagemann, S., and Jacob, D.: Impact of irrigation on the South Asian summer monsoon, Geophys. Res. Lett., 36, L20711, doi:10.1029/2009GL040625, 2009.

Schellnhuber, H. J.: Discourse: Earth System Analysis - The Scope of the Challenge, in: Earth System Analysis - Integrating science for sustainability, edited by: Schellnhuber, H. J. and Wenzel, V., Springer, Heidelberg, 1998.

Schellnhuber, H. J.: Earth system analysis and the second Copernican revolution, Nature, 402, C19-C23, 1999.

Schewe, J., Heinke, J., Gerten, D., Haddeland, I., Arnell, N. W., Clark, D. B., Dankers, R., Eisner, S., Fekete, B. M., ColónGonzález, F. J., Gosling, S. N., Kim, H., Liu, X., Masaki, Y., Portmann, F. T., Satoh, Y., Stacke, T., Tang, Q., Wada, Y., Wisser, D., Albrecht, T., Frieler, K., Piontek, F., Warszawski, L., and Kabat, P.: Multimodel assessment of water scarcity under climate change, P. Natl. Acad. Sci. USA, 111, 3245-3250, doi:10.1073/pnas.1222460110, 2014. 
Schiermeier, Q.: Water risk as world warms, Nature, 505, 7481, doi:10.1038/505010a, 2014.

Schlosser, C. A., Kicklighter, D., and Sokolov, A.: A global land system framework for integrated climate-change assessments, MIT Joint Program on the Science and Policy of Global Change, Report No. 147, http://dspace.mit.edu/handle/1721.1/38461 (last access: 6 May 2014), 2007.

Sellers, P. J.: Biophysical models of land surface processes, in: Climate system modeling, edited by: Trenberth, K. E., Cambridge University Press, Cambridge, UK, 451-490, 1992.

Sellers, P. J., Mintz, Y. C. S. Y., Sud, Y. E. A., and Dalcher, A.: A simple biosphere model $(\mathrm{SiB})$ for use within general circulation models, J. Atmos. Sci., 43, 505-531, 1986.

Sellers, P. J., Tucker, C. J., Collatz, G. J., Los, S. O., Justice, C. O., Dazlich, D. A., and Randall, D. A.: A global 1 by 1 NDVI data set for climate studies - Part 2: The generation of global fields of terrestrial biophysical parameters from the NDVI, Int. J. Remote Sens., 15, 3519-3545, 1994.

Sellers, P. J., Randall, D. A., Collatz, G. J., Berry, J. A., Field, C. B., Dazlich, D. A., Zhang, C., Collelo, G. D., and Bounoua, L.: A revised land surface parameterization $(\mathrm{SiB} 2)$ for atmospheric GCMs - Part I: Model formulation, J. Climate, 9, 676-705, 1996a.

Sellers, P. J., Meeson, B. W., Closs, J., Collatz, J., Corprew, F., Dazlich, D., Hall, F. G., Kerr, Y., Koster, R., Los, S., Mitchell, K., McManus, J., Myers, D., Sun, K.-J., and Try, P.: The ISLSCP Initiative I global datasets: surface boundary conditions and atmospheric forcings for land-atmosphere studies, B. Am. Meteorol. Soc., 77, 1987-2005, 1996b.

Shiklomanov, I. A.: World water resources, UNESCO, 1998, Paris, http://www.ce.utexas.edu/prof/mckinney/ce385d/Papers/ Shiklomanov.pdf (last access: 6 May 2014), 1993.

Shiklomanov, I. A.: Assessment of Water Resources and Water Availability in the World, Comprehensive Assessment of the Freshwater Resources of the World, WMO and SEI, Geneva, 1997.

Shiklomanov, I. A.: World water resources and water use: Present assessment and outlook for 2025, in: World water scenarios, edited by: Rijsberman, F. R., Earthscan, London, 160-203, 2000.

Short, W., Blair, N., Sullivan, P., and Mai, T.: ReEDS model documentation: base case data and model description, Golden, CO: National Renewable Energy Laboratory, http://www.nrel.gov/ analysis/reeds/documentation.html (last access: 6 May 2014), 2009

Siebert, S. and Döll, P.: The Global Crop Water Model (GCWM): Documentation and first results for irrigated crops, https://www2.uni-frankfurt.de/45217788/FHP07_ SiebertandDoell_2008.pdf (last access: 6 May 2014), 2008.

Siebert, S. and Döll, P.: Quantifying blue and green virtual water contents in global crop production as well as potential production losses without irrigation, J. Hydrol., 384, 198-217, 2010.

Siebert, S., Döll, P., Hoogeveen, J., Faures, J.-M., Frenken, K., and Feick, S.: Development and validation of the global map of irrigation areas, Hydrol. Earth Syst. Sci., 9, 535-547, doi:10.5194/hess-9-535-2005, 2005.

Siebert, S., Döll, P., Feick, S., Hoogeveen, J., and Frenken, K.: Global map of irrigation areas version 4.0.1, Food and Agriculture Organization of the United Nations, Rome, Italy, https:
//www2.uni-frankfurt.de/45218039/Global_IrrigationMap (last access: 6 May 2014), 2007.

Siebert, S., Burke, J., Faures, J. M., Frenken, K., Hoogeveen, J., Döll, P., and Portmann, F. T.: Groundwater use for irrigation - a global inventory, Hydrol. Earth Syst. Sci., 14, 1863-1880, doi:10.5194/hess-14-1863-2010, 2010.

Sitch, S., Smith, B., Prentice, I. C., Arneth, A., Bondeau, A., Cramer, W., Kaplan, J. O., Levis, S., Lucht, W., Sykes, M. T., Thonicke, K., and Venevsky, S.: Evaluation of ecosystem dynamics, plant geography and terrestrial carbon cycling in the LPJ dynamic global vegetation model, Global Change Biol., 9, 161$185,2003$.

Sivapalan, M., Savenije, H. H., and Blöschl, G.: Socio-hydrology: A new science of people and water, Hydrol. Process., 26, 12701276, 2012.

Skamarock, W. C., Klemp, J. B., Dudhia, J., Gill, D. O., Barker, D. M., Wang, W., and Powers, J. G.: A description of the advanced research WRF version 2 (No. NCAR/TN468+STR), available at: http://oai.dtic.mil/oai/oai?verb=getRecord\&metadataPrefix= html\&identifier=ADA487419 (last access: 6 May 2014), 2005.

Skliris, N. and Lascaratos, A.: Impacts of the Nile River damming on the thermohaline circulation and water mass characteristics of the Mediterranean Sea, J. Mar. Syst., 52, 121-143, doi:10.1016/j.jmarsys.2004.02.005, 2004.

Smakhtin, V., Revenga, C., and Döll, P.: A pilot global assessment of environmental water requirements and scarcity, Water Int., 29, 307-317, 2004.

Small, I., Van der Meer, J., and Upshur, R. E.: Acting on an environmental health disaster: the case of the Aral Sea, Environ. Health Perspect., 109, 547-549, 2001.

Smith, M.: CROPWAT - A computer program for irrigation planning and management, Irrigation and Drainage, Pap. 46, Food and Agric. Org. of the UN, Rome, http://www.fao.org/nr/water/ infores_databasescropwat.html (last access: 6 May 2014), 1992.

Solomon, S., Plattner, G. K., Knutti, R., and Friedlingstein, P.: Irreversible climate change due to carbon dioxide emissions, P. Natl. Acad. Sci., 106, 1704-1709, 2009.

Sophocleous, M.: Interactions between groundwater and surface water: the state of the science, Hydrogeol. J., 10, 52-67, 2002.

Sorooshian, S., Li, J., Hsu, K.-L., and Gao, X.: How significant is the impact of irrigation on the local hydroclimate in California's Central Valley? Comparison of model results with ground and remote-sensing data, J. Geophys. Res., 116, D06102, doi:10.1029/2010JD014775, 2011.

Soulis, E. D., Snelgrove, K. R., Kouwen, N., Seglenieks, F., and Verseghy, D. L.: Towards closing the vertical water balance in Canadian atmospheric models: coupling of the land surface scheme CLASS with the distributed hydrological model WATFLOOD, Atmos.-Ocean, 38, 251-269, 2000.

Steffen, W., Crutzen, P. J., and McNeill, J. R.: The Anthropocene: are humans now overwhelming the great forces of nature, Ambio, 36, 614-621, 2007.

Steffen, W., Grinevald, J., Crutzen, P., and McNeill, J.: The Anthropocene: conceptual and historical perspectives, Philos. T. Roy. Soc. A, 369, 842-867, 2011.

Steinfeld, H., Gerber, P., Wassenaar, T., Castel, V., Rosales, M., and de Haan, C.: Livestock's long shadow: Environmental issues and options, Food and Agriculture Organization - LEAD, 
Rome, Italy, http://www.fao.org/docrep/010/a0701e/a0701e00. HTM (last access: 6 May 2014), 2006.

Strzepek, K., Schlosser, A., Farmer, W., Awadalla, S., Baker, J., Rosegrant M., and Gao, X.: Modeling the global water resource system in an integrated assessment modeling framework: IGSM-WRS, MIT Joint Program on the Science and Policy of Global Change, Report No. 189, available at: http://dspace.mit. edu/handle/1721.1/61767 (last access: 6 May 2014), 2010.

Strzepek, K., Baker, J., Farmer, W., and Schlosser, C. A.: Modeling water withdrawal and consumption for electricity generation in the United States, MIT Joint Program on the Science and Policy of Global Change, Report No. 222, http://dspace.mit.edu/handle/ 1721.1/71168 (last access: 6 May 2014), 2012a.

Strzepek, K., Schlosser, A., Gueneau, A. Gao, X., Blanc, É., Fant, C., Rasheed, B., and Jacoby, H. D.: Modeling water resource system under climate change: IGSM-WRS, MIT Joint Program on the Science and Policy of Global Change, Report No. 236, http: //dspace.mit.edu/handle/1721.1/75774 (last access: 6 May 2014), 2012b.

Sulis, M., Paniconi, C., Rivard, C., Harvey, R., and Chaumont, D.: Assessment of climate change impacts at the catchment scale with a detailed hydrological model of surface-subsurface interactions and comparison with a land surface model, Water Resour. Res., 47, W01513, doi:10.1029/2010WR009167, 2011.

Takata, K., Emori, S., and Watanabe, T.: Development of the minimal advanced treatments of surface interaction and runoff, Global Planet. Change, 38, 209-222, 2003.

Tang, Q., Gao, H., Yeh, P., Oki, T., Su, F., and Lettenmaier, D. P.: Dynamics of Terrestrial Water Storage Change from Satellite and Surface Observations and Modeling, J. Hydrometeorol., 11, 156170,2010

Tao, F., Yokozawa, M., Hayashi, Y., and Lin, E.: Terrestrial water cycle and the impact of climate change, Ambio, 32, 295-301, 2003.

Taylor, C. M.: Feedbacks on convection from an African wetland, Geophys. Res. Lett., 37, L05406, doi:10.1029/2009GL041652, 2009.

Taylor, C. M., de Jeu, R. A., Guichard, F., Harris, P. P., and Dorigo, W. A.: Afternoon rain more likely over drier soils, Nature, 489, 423-426, doi:10.1038/nature11377, 2012.

Taylor, K. E., Stouffer, R. J., and Meehl, G. A.: An Overview of CMIP5 and the Experiment Design, B. Am. Meteorol. Soc., 93, 485-498, 2012.

Taylor, R. G., Scanlon, B., Döll, P., Rodell, M., van Beek, R., Wada, Y., Longuevergne, L., Leblanc, M., Famiglietti, J. S., Edmunds, M., Konikow, L., Green, T. R., Chen, J., Taniguchi, M., Bierkens, M. F. P., MacDonald, A., Fan, Y., Maxwell, R. M., Yechieli, Y., Gurdak, J. J., Allen, D. M., Shamsudduha, M., Hiscock, K., Yeh, P. J.-F., Holman, I., and Treidel, H.: Ground water and climate change, Nat. Clim. Change, 3, 322-329, 2013.

Tesfa, T. K., Li, H.-Y., Leung, L. R., Huang, M., Ke, Y., Sun, Y., and Liu, Y.: A subbasin-based framework to represent land surface processes in an Earth system model, Geosci. Model Dev., 7, 947963, doi:10.5194/gmd-7-947-2014, 2014.

Tharme, R. E.: A global perspective on environmental flow assessment: emerging trends in the development and application of environmental flow methodologies for rivers, River Res. Appl., 19, 397-441, doi:10.1002/rra.736, 2003.
Thenkabail, P. S., Biradar, C. M., Noojipady, P., Dheeravath, V., Li, Y., Velpuri, M., Gumma, M., Gangalakunta, O. R. P., Turral, H., Cai, X., Vithanage, J., Schull, M. A., and Dutta, R.: Global irrigated area map (GIAM), derived from remote sensing, for the end of the last millennium, Int. J. Remote Sens., 30, 3679-3733, 2009.

Trenberth, K. E. (Ed.): Climate Systems Modeling, Cambridge University Press, Cambridge, UK, 1992.

Trenberth, K. E. and Asrar, G. R.: Challenges and opportunities in water cycle research: WCRP contributions, Surv. Geophys., 35, 515-532, 2012.

Trenberth, K. E. and Dai, A.: Effects of Mount Pinatubo volcanic eruption on the hydrological cycle as an ana$\log$ of geoengineering, Geophys. Res. Lett., 34, L15702, doi:10.1029/2007GL030524, 2007.

Tuinenburg, O. A., Hutjes, R. W. A., Jacobs, C. M. J., and Kabat, P.: Diagnosis of Local Land-Atmosphere Feedbacks in India, J.f Climate, 24, 251-266, 2011.

UN: Statistical Yearbook, Stat. Div., New York, 1997.

USDA: 2002 census of agriculture, National Agricultural Statistics Service, http://www.agcensus.usda.gov/Publications/2002/ (last access: 6 May 2014), 2002.

USDA: 2007 census of agriculture, Farm and Ranch Irrigation Survey, Volume 3, Special studies, part 1, http://www.agcensus.usda.gov/Publications/2007/Online Highlights/FarmandRanch_IrrigationSurvey/fris08.pdf (last access: 6 May 2014), 2008.

van Beek, L. P. H., Wada, Y., and Bierkens, M. F. P.: Global monthly water stress: 1 . Water balance and water availability, Water Resour. Res., 47, W07517, doi:10.1029/2010WR009791, 2011.

van Woerden, J., Diedericks, J., and Klein-Goldewjik, K.: Data management in support of integrated environmental assessment and modelling at RIVM - including the 1995 RIVM Catalogue of International Data Sets, RIVM Report no. 402001006, National Institute of Public Health and the Environment, Bilthoven, the Netherlands, 1995.

Vargas-Yáñez, M., Moya, F., García-Martínez, M. C., Tel, E., Zunino, P., Plaza, F., Salat, J., Pascual, J., LópezJurado, J. L., and Serra, M.: Climate change in the Western Mediterranean sea 1900-2008, J. Mar. Syst., 82, 171-176, doi:10.1016/j.jmarsys.2010.04.013, 2010.

Vassolo, S. and Döll, P.: Global-scale gridded estimates of thermoelectric power and manufacturing water use, Water Resour. Res., 41, W04010, doi:10.1029/2004WR003360, 2005.

Verseghy, D. L.: CLASS - A Canadian land surface scheme for GCMs I. Soil model, Int. J. Climatol., 11, 111-133, 1991.

Verseghy, D. L.: The Canadian land surface scheme (CLASS): Its history and future, Atmos.-Ocean, 38, 1-13, 2000.

Verseghy, D. L., McFarlane, N. A., and Lazare, M.: CLASS - A Canadian land surface scheme for GCMs II. Vegetation model and coupled runs, Int. J. Climatol., 13, 347-370, 1993.

Vitousek, P. M., Mooney, H. A., Lubchenco, J., and Melillo, J. M.: Human domination of Earth's ecosystems, Science, 277, 494499, 1997.

Voisin, N., Liu, L., Hejazi, M., Tesfa, T., Li, H., Huang, M., Liu, Y., and Leung, L. R.: One-way coupling of an integrated assessment model and a water resources model: evaluation and implications of future changes over the US Midwest, Hydrol. Earth Syst. Sci., 17, 4555-4575, doi:10.5194/hess-17-4555-2013, 2013. 
Vörösmarty, C. J. and Sahagian, D.: Anthropogenic disturbance of the terrestrial water cycle, BioScience, 50, 753-765, 2000.

Vörösmarty, C. J., Sharma, K. P., Fekete, B. M., Copeland, A. H., Holden, J., Marble, J., and Lough, J. A.: The storage and aging of continental runoff in large reservoir systems of the world, Ambio, 26, 210-219, 1997.

Vörösmarty, C. J., Federer, C. A., and Schloss A. L.: Potential evaporation functions compared on US watersheds: Possible implications for global-scale water balance and terrestrial ecosystem modeling, J. Hydrol., 207, 147-169, 1998.

Vörösmarty, C. J., Leveque, C., and Revenga, C.: Millennium Ecosystem Assessment Volume 1: Conditions and Trends, chap. 7: Freshwater ecosystems, Island Press, Washington, D.C., USA, 165-207, 2005.

Wada, Y., van Beek, L. P. H., van Kempen, C. M., Reckman, J. W. T. M., Vasak, S., and Bierkens, M. F. P.: Global depletion of groundwater resources, Geophys. Res. Lett., 37, L20402, doi:10.1029/2010GL044571, 2010.

Wada, Y., van Beek, L. P. H., Viviroli, D., Dürr, H. H., Weingartner, R., and Bierkens, M. F. P.: Global monthly water stress: 2. Water demand and severity of water stress, Water Resour. Res., 47, W07518, doi:10.1029/2010WR009792, 2011.

Wada, Y., van Beek, L. P. H., and Bierkens, M. F. P.: Nonsustainable groundwater sustaining irrigation: A global assessment, Water Resour. Res., 48, W00L06, doi:10.1029/2011WR010562, 2012.

Wada, Y., Wisser, D., Eisner, S., Flörke, M., Gerten, D., Haddeland, I., Hanasaki, N., Masaki, Y., Portmann, F. T., Stacke, T., Tessler, Z., Schewe, J.: Multimodel projections and uncertainties of irrigation water demand under climate change, Geophys. Res. Lett., 40, 4626-4632, 2013.

Wada, Y., Wisser, D., and Bierkens, M. F. P.: Global modeling of withdrawal, allocation and consumptive use of surface water and groundwater resources, Earth Syst. Dynam., 5, 15-40, doi:10.5194/esd-5-15-2014, 2014.

Walko, R. L., Band, L. E., Baron, J., Kittel, T. G. F., Lammers, R., Lee, T. J., Ojima, D., Pielke, R. A., Taylor, C., Tague, C., Tremback, C. J., and Vidale, P. L.: Coupled atmosphere-biophysicshydrology models for environmental modeling, J. Appl. Meteorol., 39, 931-944, 2000.

Wei, J., Dirmeyer, P. A., Wisser, D., Bosilovich, M. G., and Mocko, D. M.: Where does the irrigation water go? An estimate of the contribution of irrigation to precipitation using MERRA, J. Hydrometeorol., 14, 275-289, 2013.

Wise, M. and Calvin, K.: GCAM 3.0 agriculture and land use: technical description of modeling approach, Pacific Northwest National Laboratory, Richland, WA, https://wiki.umd.edu/ gcam/images/8/87/GCAM3AGTechDescript12511.pdf (last access: 6 May 2014), 2011.
Wise, M., Calvin, K., Thomson, A., Clarke, L., Bond-Lamberty, B., Sands, R., Smith, S. J., Janetos, A., and Edmonds, J.: The implications of limiting $\mathrm{CO}_{2}$ concentrations for agriculture, landuse change emissions and bioenergy, Technical report PNNL17943, available at: http://www.usitc.gov/researchand_analysis/ economics_seminars/2009/200902_co2landuse.pdf (last access: 6 May 2014), 2009a.

Wise, M., Calvin, K., Thomson, A., Clarke, L., Bond-Lamberty, B., Sands, R., Smith, S. J., Janetos, A., and Edmonds, J.: Implications of limiting $\mathrm{CO}_{2}$ concentrations for land use and energy, Science, 324, 1183-1186, 2009b.

Wisser, D., Frolking, S., Douglas, E. M., Fekete, B. M., Vörösmarty, C. J., and Schumann, A. H.: Global irrigation water demand: Variability and uncertainties arising from agricultural and climate data sets, Geophys. Res. Lett., 35, L24408, doi:10.1029/2008GL035296, 2008.

Wisser, D., Fekete, B. M., Vörösmarty, C. J., and Schumann, A. H.: Reconstructing 20th century global hydrography: a contribution to the Global Terrestrial Network-Hydrology (GTN-H), Hydrol. Earth Syst. Sci., 14, 1-24, doi:10.5194/hess-14-1-2010, 2010.

Wood, E. F., Roundy, J. K., Troy, T. J., van Beek, L. P. H., Bierkens, M. F. P., Blyth, E., de Roo, A., Döll, P., Ek, M., Famiglietti, J., Gochis, D., van de Giesen, N., Houser, P., Jaffé, P. R., Kollet, S., Lehner, B., Lettenmaier, D. P., Peters-Lidard, C., Sivapalan, M., Sheffield, J., Wade, A., and Whitehead, P.: Hyperresolution global land surface modeling: meeting a grand challenge for monitoring Earth's terrestrial water, Water Resour. Res., 47, W05301, doi:10.1029/2010WR010090, 2011.

WRI: World Resources 1998-99, Oxford Press, New York, USA, 1998.

WRI: World Resources 2000-01, Oxford Press, New York, USA, 2000.

Yoshikawa, S., Cho, J., Yamada, H. G., Hanasaki, N., and Kanae, S.: An assessment of global net irrigation water requirements from various water supply sources to sustain irrigation: rivers and reservoirs (1960-2050), Hydrol. Earth Syst. Sci., 18, 4289-4310, doi:10.5194/hess-18-4289-2014, 2014.

Zhao, M. and Dirmeyer, P. A.: Production and analysis of GSWP-2 near-surface meteorology data sets (Vol. 159), Center for OceanLand-Atmosphere Studies, Calverton, http://ww.w.monsoondata. org/gswp/gswp2data.pdf (last access: 6 May 2014), 2003.

Zhao, M., Pitman, A. J., and Chase, T.: The impact of land cover change on the atmospheric circulation, Clim. Dynam., 17, 467477, 2001. 